Uşak Üniversitesi Sosyal Bilimler Dergisi

$2014,7 / 2$

\title{
Atatürk Üniversitesinde İnternet Bankacılığının Kullanımını Etkileyen Faktörlerin Belirlenmesi
}

\author{
Erkan OKTAY* \\ Kenan ORÇANLI ${ }^{* *}$
}

\section{Özet}

Günümüzde, meydana gelen teknolojik gelişmeler karşısında, birçok sektörde değişim ve gelişim yaşanmaktadır. Bu değişim ve gelişim karşısında işletmeler, özellikle bankacılık sektöründe, rakiplerinden geri kalmamak için müşterilerine sunduğu hizmet alanlarını geliştirmek zorunda kalmaktadır.

Diğer birçok ülkede olduğu gibi Türkiye'de de bankalar rekabetçi pozisyonlarını sürdürebilmek ve müşterilerine hizmet sağlamak için farklı iletişim kanalları kullanmaktadır. Teknolojik gelişmeler, artan operasyon maliyetleri ve daha ileri müşteri memnuniyeti sağlama anlayışı, bankaları şubelerin dışında yeni hizmet kanalları bulmaya itmiştir. Bu anlayışın sonucu, internet altyapısına ve bu altyapıyı kullanabilecek bilgisayar, cep telefonu gibi bir araca sahip müşterilerine internet bankacılığ 1 adı altında zaman ve mekândan bağımsız bir hizmet sunmaya zorlamıştır.

Yapılan çalışmanın amacı, Atatürk Üniversitesi'nde internet bankacılığını kullanan akademik personelin davranışlarını ve bu davranışlara etki eden faktörleri tespit etmeye yöneliktir. Bu kapsamda, “Atatürk Üniversitesi'nde görev yapan akademik personeli internet bankacılığı hizmetlerini kullanmaya iten motivasyon nedir?" ve "Hangi faktörler buna neden olur?" sorularına yanıt aranmaya çalışılmıştır. Yapılan analizde, İki Kategorili Lojistik Regresyon Yöntemi kullanılmıştır. Çalışmanın sonunda, Atatürk Üniversitesinde görev yapan akademisyenler arasında internet bankacılığının kullanımında etkili olan değişkenlerin cinsiyet, yaş, temel bilim dalı ve araba sahipliği olduğu tespit edilmiştir.

Anahtar Kelimeler: İnternet Bankacılığı, Hizmet, Lojistik Regresyon, Analiz

\section{Determining Factors Of Affecting Usage Of Internet Banking In Atatürk University}

\footnotetext{
Abstract

* Prof.Dr. Atatürk Üniversitesi, İ̈BF, Ekonometri Bölümü.

** Atatürk Üniversitesi, Sosyal Bilimler Enstitüsü.
}

Today, following the technological advances, so many sectors have been experiencing changes and developments. In the light of these changes and 
developments corporations, especially in banking sector, to avoid lagging behind among their competitors, have been forced to improve the service areas which have been offered to their clients.

In Turkey, as well as in many other countries, banks use the different communication channels to sustain the competitive positions in the sector and to provide service to their clients. Technological advances, increasing operation costs and understanding of higher customer satisfaction have propelled the banks to try to find the new service channels. As a result of this, with the term "internet banking", the banks have been impelled to service their clients who use internet infrastructure and have computer, mobile phone etc. available to use this infrastructure which is independent from time and place.

The aim of our study is to determine the behavior and its factors of the academic staff using internet banking and working at Atatürk University. In this context, we have tried to answer these questions "What could be the motivation of akademic people, who work in Atatürk University, to use internet banking?" and "Which factors would cause this?". In the analysis, binary logistic regression analysis was used. At the end of the study, among academics who work in Atatürk University, as effective variables in internet banking use, gender, age, basic science major and car ownership have been identified.

Key Words: Internet Banking, Services, Logistic Regression, Analysis

\section{Giriş}

İçinde bulunduğumuz dönemde finansal piyasalarda yaşanan gelişmeler, teknolojik ilerlemeler ve en önemlisi müşteri tercihlerinde meydana gelen değişiklikler, özellikle bankacılık sektöründe de kurumlar arası rekabetin artmasına yol açmıştır (Pala ve Kartal, 2010: 44). Artan bu rekabet karşısında, bankaların müşterilerini etkileyecek ve sadakatlerini artıracak yeni stratejiler geliştirmeleri, ayakta kalabilmelerini sağlayacak en önemli etken haline gelmiştir (Duruer vd., 2009: 134). Bu bağlamda, bankaların alternatif hizmet kanallarını kullanmaya başlamaları da bir zorunluluk olarak ortaya çıkmıştır.

Özellikle rekabetçi bir pazarda, yeni müşterilerin dikkatini çekmek, eski müşterilerle ilişkileri geliştirmek ve sürdürmek için teknoloji kullanımı önemli hale gelmiştir. Bankacılık alanındaki uygulamalar sonucu ortaya çıkan internet bankacılığı; banka müşterilerinin interneti kullanarak bankacılık işlemlerini gerçekleştirmeleri olarak ifade edilebilmektedir 
(Ustasüleyman ve Eyüpoğlu, 2010: 12). İnternet bankacilığ1, bankanın bir web sayfası oluşturarak fon transferi, ürünleri ve hizmetleri hakkında bilgi vermesi, anlık işlemler, hesaplara giriş, finansal ürünler ve hizmetler satın almak gibi fonksiyonları kapsamaktadır.

Çalışma saatleri dışında bankacılık işlemini gerçekleştirme, maliyet ve zaman tasarrufu sağlama, kolayca günlük hesap bilgileri görebilme ve kontrol edebilme, piyasadaki değişikliklere hızlı karşlık verme, şikâyetlere hızlıca cevap verme gibi hem müşterilere hem de bankalara internet bankacılığı geleneksel bankacılığa göre avantajlar sunmaktadır. (Ustasüleyman ve Eyüpoğlu, 2010: 12).

İnternet bankacılığından beklenen faydaların sağlanabilmesi, ancak internet bankacılığının yaygın bir biçimde kullanılabilmesiyle ilişkilidir. Bu kapsamda, internet bankacıllı̆g kullanımına etki eden faktörlerin bilinmesi önem taşır. Literatürde, Dünya'da ve Türkiye'de internet bankacıllğının kullanımını etkileyen faktörlerin belirlenmesine yönelik birçok çalışma yapılmıştır. Bu çalışmaların bazılarında internet bankacılığı kullanma veya kullanmama durumunu etkileyen faktörler belirlenmeye çalışılırken, bazı çalışmalarda ise, internet bankacılı̆̆ında bireylerin internet bankacılığını benimsemesini etkileyen faktörlerin Yapısal Eşitlik Modeli ile tespit edilmeye çalışılmıştır.

Yapılan çalışma da amaç, Atatürk Üniversitesi'nde görev yapan öğretim üyeleri ve diğer personel ile yapılan bir anket uygulamasıyla banka müşterilerinin görüşleri doğrultusunda internet bankacılığının kullanımını etkileyen faktörleri İki Kategorili Lojistik Regresyon Yöntemi ile belirlemek, internet bankacılığına yönelik tutumları incelemek ve elde edilen bulgulara dayanarak genel bir değerlendirme yapmaktır.

$\mathrm{Bu}$ çalışmanın diğer çalışmalardan farkı kullanılan yönteminden kaynaklanmaktadır. Literatürde, internet bankacılığın kullanımına etki eden faktörlerin belirlenmesine yönelik İki Kategorili Lojistik Regresyon Yöntemi ile tespit edilmeye yönelik bir çalışmaya rastlanılmamıştır.

\section{Literatür Özeti}

Sathye (1999) tarafından Avustralya'da yapılan araştırmada, 265 tüketici ve 324 işletmeye bir anket uygulaması gerçekleştirilmiştir. İnternet bankacılığının yaygınlaşmasındaki en önemli etkenlerin güvenlik kaygısı ve haberdar olmamak olduğu sonucu elde edilmiştir.

Jayawardhena ve Foley (2000) tarafından yapılan araştırma sonucunda, web sitesinin yüklenme hızı ile müşterinin tatminkarlığı arasında güçlü bir ilişki olduğu açıklanmıştır. Ayrıca içerik, dizayn, 
interaktiflik, rahatça site içi gezinme ve güvenlik faktörlerinin de pozitif yönlü ilişkili olduğu ifade edilmiştir. Ayrıca, Broderick ve Vachirapornpuk (2002) ise, internet bankacılığı müşterilerine yönelik gözlemleri sonucunda yukarıda belirtilen faktörlerin iyi olmamasının müşteri üzerinde önemli ölçüde olumsuz etkisi olduğunu belirtmektedir.

Kolodinsky, Hogarth ve Shue (2000) yaptıkları çalışma da, elektronik bankacılık hizmetlerinin tümünü ele aldığımızda demografik değişkenlerden çok, müşterilerin bireysel alışkanlıklarının ve inanışlarının uygulamalar üzerinde daha fazla etkili olduğunu ortaya koymuşlardır.

Polatoğlu ve Ekin (2001) tarafından Garanti Bankası müşterilerine yönelik yapılan araştırma sonucunda, müşterilerin genel olarak bankanın internet bankacılığı hizmetinden memnun olduğu, müşterilerin internet bankacılığını tercih etme nedenlerinin başında zaman ve maliyet unsurlarının geldiği tespit edilmiştir. Müşterilerin şube bankacılı̆̆ 1 ile karşılaştırdıklarında internet bankacılığının fiyat ve rahatlık açısından daha avantajlı olduğunu ifade ettikleri görülmüştür.

Liao ve Chung (2002) tarafından Singapur'da yapılan internet bankacılığı kullanmama nedenlerine yönelik bir çalışma da, "internet bankacılığının güvenilir olmadığı" düşüncesinin kullanıcılar üzerinde büyük etkisi olduğu sonucu elde edilmiştir.

Sun ve Han (2002) tarafından yapılan çalışma da, Kore'de beş bankanın sitelerine koyulan anket aracılığıyla tüketicilerin internet bankacılığının sağladığı fayda ve kullanım kolaylığı ve beklentilerinin karşılandığı, ancak güven kaygısının internet bankacılığı kullanımına karşı tutumun en önemli belirleyicilerinden biri olduğu sonucuna varılmıştır.

Li (2002) tarafından yapılan çalışmada, gelişen internet bankacılığı uygulamalarının işlem kolaylığı sağlama unsuru olmanın yanı sıra, bankaların yeni düşünceler bulmaya zorlayan bir rekabet ortamı oluşturduğu ifade edilmiş, internet bankacılığının yeni iş modellerinde kullanılması ve banka servislerinin buna göre yeniden yapılandırılması gerektiği açıklanmıştır.

Matilla, Karjaluota ve Pento (2003) yaptıkları araştırma da, 65 yaş üzeri olan bireysel banka müşterilerinin internet bankacılığına bakış açılarını incelemişlerdir. 220 anket uygulamasının sonuçlarına göre, bu yaş grubunun internet bankacılığı kullanımını zor kabullendikleri ve çok zor benimsedikleri tespit edilmiştir. 
Pew (2003) tarafından yapılan araştırma sonucunda, ABD'de internet bankacılığına yönelik en motive edici unsurların 24/7 erişim imkânının ve zaman tasarrufunu olduğu tespit edilmiştir.

Sohail ve Shanmugham (2003) tarafından Malezya' da 300 üniversite öğrencisi ile internet ortamında yapılan araştırma sonucunda, internet bankacılığı kullanımını etkileyen faktörlerin internete ulaşabilme, değişikliğe karşı tepki, bilgisayar ve internet bağlantı maliyetleri, hatalı işlem ve dolandırılma durumlarında bankaya karşı duyulan güvensizlik, rahatlık ve kullanım kolaylığı olarak belirlenmiştir.

Rotchanakitumnuai ve Speece (2003) tarafından Tayland'da yedi tane internet bankacilığı kullanan ve sekiz tane kullanmayan işletmenin yöneticileri ile yapılan yüz yüze görüşmeler sonucunda, internet bankacılığı kullanımının yaygınlaşmasının önündeki en büyük engelin güvenlik kaygısı olduğu sonucuna varılmıştır.

Li ve Worthington (2004) internet bankacıllğg hizmetlerine yönelik olacak talebin belirlenmesinde öncelikli olarak internet erişimine sahip müşterilerin sayılarının tespit edilmesi gerektiği, bununla birlikte internet bağlantı hızının ve maliyetinin önemi vurgulamışlardır. Ayrıca Li ve Worthington (2004) internet bankacılı̆̆ 1 işlemlerinde müşteri güveninin sağlanmasının diğer bir önemli faktör olduğunu ileri sürmüşlerdir.

Akıncı, Aksoy ve Atılgan (2004) tarafından öğretim elemanlarına email aracılığıyla uygulanan anket sonucunda, internet bankacilı̆̆ kullanmayanların işlem yaparken karşılaşabilecekleri her türlü problem için yeterli yardım alamayacaklarına inandıkları, geleneksel bankacılık yolu ile yapılan işlemlerde daha az problemle karşılaşacaklarına inandıkları görülmüştür.

Shergill ve Li (2005) internet bankacilığ1 müşterilerine yönelik yaptıkları araştırma sonucunda, gizlilik ve etik standartlarına kadınların erkeklerden daha fazla önem verdiklerini tespit etmişlerdir.

Kim, Widdows ve Yılmazer (2005) internet bankacılığı uygulamasını benimsemede etkili olan unsurlarını tespit etmek amacıyla, 2001 Tüketici Finansmanı Araştırması'ndan faydalanmışlardır. Çalışma da, internet bankacılığını benimsemeye yönelik bir model oluşturulmuştur. Sonuç olarak, tüketicilerin yeteneği, tutum ve zaman maliyeti fırsatçllı̆̆ gibi nedenlerin internet bankacılığını kullanım kararını önemli ölçüde etkilediği tespit edilmiştir. Genç ve eğitimli tüketicilerin internet bankacılığı kullanımını benimsemede diğer müşterilere göre daha iyi oldukları da görülmüştür. 
Usta (2005) internet kullanan tüketicilerin internet bankacilığı kullanmama nedenlerini belirlemeyi amaçlamıştır. Araştırmanın amaçlarına uygun olarak bazı banka yöneticilerinin fikirleri alınmış ve 30 memur üzerinde pilot uygulama yapılmıştır. Anakütle olarak ülkemizdeki kamu kurum ve kuruluşlarında çalışan memurlardan internet tecrübesi olanlar seçilmişlerdir. E-posta yoluyla yapılan anket uygulamasında, 5000 örnek kitle seçilmiş ve illerin ülke nüfusuna göre örnek hacmi illere paylaştırılmıştır. Sonuç olarak, ülkemizdeki memur tüketicilerden internet kullananların internet bankacılığı kullanımını etkileyen en büyük faktör olarak güvenlik kaygısı olduğu sonucuna varılmıştır.

Y1lmaz (2006) bilgi iletişim teknolojilerindeki gelişmelerin bankacılık işlemleri üzerine olan etkilerini incelemiştir. Bankacılık sektöründe yaşanan yoğun teknolojik değişimin farklı hizmet kanallarının ortaya çıkmasını sağladığını ifade etmiş ve bunları açıklamıştır. İnternet bankacılığının tanımı, gelişimi ve internet bankacılığı kullanımında nelerin göz önünde bulundurulmasına yönelik bilgiler sunulmuştur.

Gülmez ve Kitapçı (2006) internet bankacılığı kullanıcılarının beklentilerini belirlemek amaciyla Cumhuriyet Üniversitesi'nde internet bankacılığı kullanan 176 akademik ve idari personel üzerinde anket uygulaması gerçekleştirmişlerdir. Müşterilerin nelere dikkat ettiği, nelerin önemli olduğu, hangi bankacılık hizmetlerini internet üzerinden yaptıklarını incelemişlerdir. 2003 yılı Kasım ve Aralık aylarında Cumhuriyet Üniversitesine bağlı akademik ve idari personele e-posta yoluyla yapılan anket uygulaması sonucunda, elde edilen veri setine faktör analizi uygulanmıştır. $\mathrm{Bu}$ analiz sonucunda sırasıyla web sitesinin görünümü ve hızı, hizmet sorunlarının anında çözümü ve güvenlik faktörlerinin kullanıcılar açısından öncelikli olduğu tespit edilmiştir.

Chiemeke, Ewiekpaefe ve Chete (2006) 12 büyük Nijerya bankasında yaptıkları araştırmada, internet bankacılığı kullanımında güvenlik ve iletişim altyapı sorunlarının önemli kısıtlayıcı faktörler olduğunu belirtmişlerdir.

Lichtenstein ve Williamson (2006) Avustralya'da banka müşterilerinin internet bankacılığı kullanımını etkileyen başlıca faktörlerin neler olduğunu ve bunların nasıl bir etkileşim içerisinde olduğunu incelemişlerdir. Bulgulara göre müşteriler, internet hizmetlerinin kullanımında risk altında olduklarını ve bu şekilde yapılan hizmet 
uygulamaları için derinlemesine destek sağlanması gerektiğini ifade etmişlerdir.

Padachi, Rojid ve Seetanah (2007) Mauritus Adası'nda internet bankacılığına uyum sürecini etkileyen faktörlerin incelenmesi üzerine bir çalışma gerçekleştirmişlerdir. 200 cevaplayıcının katıldığı anket çalışması sonucunda, kullanıcıların internet bankacılığını hesaplar arası transfer, havale, kerdi kartı hesabı ödeme şeklinde kullanımlarının fazla olduğu gözlemlenmiştir. İnternet bankacılığı kullanan ve kullanmayanlar arasında önemli bir demografik farklılığın olmadığı (yaş, eğitim ve aylık ortalama gelire göre) görülmüştür. Mauritus'da internet bankacılığına uyum sürecini etkileyen en önemli unsurun tespitine yönelik yapılan faktör analizi sonucunda, kullanım kolaylığının en önde geldiği ortaya koyulmuştur.

Barışık ve Temel (2007) bankacılık sektöründe internetin kullanımının artması sonucunda internet bankacılığına yönelik dolandırıcılık saldırılarında artış söz konusu olduğunu ifade etmiştir. Bu amaçla internet bankacılığı kullanımında güvenlik unsurlarının bilinilirliği ve kullanılabilirliğini tespit etmeye yönelik uygulama gerçekleştirmişlerdir. Çalışma da, Zonguldak Karaelmas Üniversitesi İİBF öğrenci ve öğretim üyelerinden 16 öğretim üyesi, 16 araştırma görevlisi ve 311 öğrenci örneklem olarak seçilmiştir. İnternet bankacılığının kullanımı ve güvenlik unsurlarına verilen önemin öğrenciler ve öğretim elemanları arasında farklı olduğu ve bu farklılığın internet bankacılığı kullanımını etkilediği sonucuna varmışlardır.

Amin (2007) çalışmasında Malezya'daki üniversite öğrencileri arasındaki internet bankacılığı kullanımına olan ilgiyi incelemiştir. Teorik olarak Teknolojiyi Kullanma Modeli'nin uyarlanmış versiyonu araştırmanın temelini oluşturmuştur. Model, algılanan faydalılık, algılanan kullanım kolaylığı, algılanan güvenilirlik ve bilgisayarın etkinliği olmak üzere dört değişkeni kapsamaktadır. Sonuç olarak, üniversite öğrencilerinin internet bankacılığı kullanımını kabullenmelerinde faydalılık, kullanım kolaylığı ve bilgisayarın etkinliği arasında kuvvetli ilişki olduğu, algılanan güvenilirlik ile ilişkinin olmadığı, olumsuz etkisi olduğu tespit edilmiştir.

Çatı, Öncü ve Koçoğlu (2007) internet bankacilığının kullanılıp kullanılmadığını, ne kadar kullanıldığını, araştırmaya katılanların özelliklerine göre internet bankacıllğı kullanımının farklılaşıp farklılaşmadığının tespitine yönelik alan uygulaması gerçekleştirmişlerdir. Alan çalışması, Düzce Üniversitesi'nde görevli 205 akademik ve idari personel ile yüz yüze anket uygulaması gerçekleştirilerek yapılmıştır. Sonuç olarak, internet bankacılığı kullanım düzeyi etkileyen değişkenlerin eğitim 
durumu, gelir düzeyi ve çalışma pozisyonlarına göre farklılık gösterdiği tespit edilmiştir. Ayrıca, internet bankacılığı kullanımını etkileyen değişkenler ile internet bankacıllğı kullanım düzeyi arasında ilişki olduğu saptanmıştır.

Floros (2008) tarafından yapılan çalışma da, internet bankacılığı konusunda internet bankacılığı web sitelerinin performansı araştırılmıştır. Bu kapsamda, Floros (2008) internet bankacilığı hizmeti sunan web sitelerine erişim yüzdesi (müşteri olan), yoğunluk derecesi ve her bir internet bankacılığı kullanıcısının günde kaç defa siteyi ziyaret ettiği gibi faktörleri incelemiştir. Yunanistan'da faaliyette olan internet bankacılığı hizmeti sunan web sitelerinin 2008'deki performansını ölçmeyi amaçlayan çalışma sonucunda, sadece büyük bankaların performansının iyi olduğu, ancak bu bankalarında Avrupa'daki diğer önemli bankalara göre düşük seviyede olduğu görülmüştür.

Migdadi (2008) Ürdün'deki ticari bankaların hizmetlerinin kalitesini karşılaştırmak amacıyla nicel değerleme metodu kullanmış ve bankaların web sitelerini değerlendirmek amacıyla 16 ticari banka incelemiştir. Ürdün bankalarının internet bankacılığı hizmetlerinde kaliteli oldukları, zengin içerik sundukları ve site içi gezinmenin rahat olduğu tespit edilmiştir. Ancak ana sayfanın yüklenme hızının ve siteye erişilebilirliğin daha geliştirilmesi gerektiği de ifade edilmiştir.

Liu (2008) çalışmasında, internet bankacılığının dijital sermaye kazanımı ile iş performansı arasındaki ilişkiyi ortaya koymaya çalışmıştır. İnternet kullanımındaki hızlı artış ve elektronik bankacılığa yönelik kaynak aktarımları araştırmacıların dikkatlerinin internet bankacılığına doğru kaymasına sebep olduğunu ifade etmiştir. Araştırma sonucunda, dijital sermayenin dört ölçütünün iş performansı ile önemli ölçüde pozitif yönlü ilişkili olduğu görülmüştür.

Gao ve Owolabi (2008) Nijerya'da müşterilerin internet bankacılığını benimsemelerinde etkili olan faktörleri tespit etmeyi amaçlamıştır. Sonuç olarak, internet bankacılığı farkındalığı, bilgisayar ve internete erişilebilirlik, uygunluk, gizlilik, maliyetler ve internet bankacilığ hakkındaki bilgi ve destek hizmetlerinin sağlanması unsurlarının etkili olduğu görülmüştür. Çalışmanın sonuçlarına göre, Nijerya'da internet bankacılığının müşteriler tarafından daha kullanılır hale gelebilmesi amacıyla internet bankacılı̆̆ının faydalarının ve detaylarının müşterilere aktarılması gerektiği önerisi getirilmiştir. 
Altan ve Karasioğlu (2009) internet bankacılığı hizmetlerinin toplum katmanları tarafından nasıl ve ne ölçüde kullanıldığını anket uygulaması ile tespit etmeye çalışmışlardır. Toplam 298 denek kullanılan anket uygulaması sonucunda, toplumun \% 32,9'unun internet bankacılığından faydalandı̆̆ tespit edilmiştir. Ayrıca, erkeklerin kadınlardan, gençlerin orta yaş ve üzerindekilerden, geliri ve eğitim düzeyi yüksek olanların düşük olanlardan internet bankacılığını daha fazla kullandığı sonucunu elde etmişlerdir.

\section{Uygulama}

\section{Araștırmanın Amacı ve Önemi}

Comscore'un Ağustos 2012 tarihli verilerine göre, Türkiye'de 15 yaş üstü evden ve işyerinden internete bağlanan 23.1 milyon internet kullanıcısı bulunmaktadır. Comscore'un ölçüm verileri, ev ve işyeri dışında internet kafe gibi yerlerde ortak paylaşılan bilgisayarlardan ve mobil cihazlardan internete yapılan erişimi içermemektedir. Türkiye' de internet kafe kullanımı hala yüksek bir oranda olmasından dolayı Türkiye'de internet kullanıcısı sayısının bu rakamdan yaklaşık 10 milyon kişi daha fazla olduğu tahmin edilmektedir. Bu rakam, Türkiye nüfusunun yaklaşık \% 45,8'dir. Türkiye, Comscore'un 15 yaş ve üstü, evden ve işyerinden internete bağlanan kullanıcıları baz alarak yaptığı çalışmada, Ağustos 2012 tarihli verilere göre 23,1 milyon internet kullanıcısı ile Avrupa'da en kalabalık 6. internet nüfusuna sahip ülke durumundadır. Bu sıralamada bir önceki yılın aynı dönemine göre 8. sırada iken, Ağustos 2012 tarihi itibarıyla 6. siraya ilerlemiştir (www.webrazzi.com). Bu kapsamda, ülkemizde internetin hızlı ve yoğun bir şekilde artması birçok sektörü etkilerken bunlardan en çok etkilenen alanlardan biride bankacılık sektörüdür. Bu kapsamda, bankacılık sektöründe hizmetlerden biri olan internet bankacıllğı kullanımını etkileyen faktörlerin tespit edilmesi büyük önem taşımaktadır ve ayrıca, Türkiye'de sunulan internet bankacılığı hizmetleriyle ile ilgili müşteri algılarının, hoşlandıkları ve hoşlanmadıkları yönlerinin ortaya çıkarılması gereklidir. Bu çalışma sonuçlarının Türkiye'de internet bankacılığı kullanma oranının yükselmesine katkı sağlayacağı düşünülmektedir.

\section{Kullanılan Ölçme Aracı ve Yöntemi}

Araştırma verileri yüz yüze yapılan anket yoluyla toplanmıştır. Anket formu, benzer çalışmalar incelenerek iki ana bölüm olarak oluşturulmuştur. Anketin birinci bölümünde, demografik özelliklerle ilgili sorular yer almıştır. Böylece katılımcıların cinsiyeti, yaşı, araba sahipliği, konut sahipliği, bilgisayar sahipliği, eğitim durumu, mesleği, temel bilim alanı, akademik unvanı, ailedeki beraber yaşadığı kişi sayısı ve aylık geliri öğrenilmiştir. İkinci bölümde ise; katılımcılara, internet bankacılığını ne 
sıklıkta kullandıkları, internet bankacılığını kullanmaya sebep olan faktörlerin ne olduğu, internet güvenliğini nasıl sağladıkları, internet bankacılığı hizmetler ile ilgili görüşleri ve internet bankacılığı kullanmayanlara neden kullanmadıkları sorulmuştur. İkinci bölümde katılımcların internet bankacılığı ile düşüncelerini 5’li Likert tipi ölçek ile ölçmeyi amaçlayan ifadeler yer almaktadır. Ankette geçerlilik ve güvenirlik analizi yapılmıştır. Yapılan güvenirlik analizi sonucunda Cronbach Alfa değeri, \%72,6 olarak belirlenmiştir. Bu sonuç araştırmada geliştirilen testin oldukça güvenilir olduğunu göstermektedir

\section{Anakütle ve Örneklem Hacminin Belirlenmesi}

Araştırmada kullanılacak veri setini elde etmek için, anket uygulaması Atatürk Üniversitesi çalışanları üzerinde yüz yüze anket tekniği ile elde edilen birincil verilere dayanılarak yapılmıştır. Veri seti, yatay kesit verilerinden oluşmaktadır. Atatürk Üniversitesinde, anketin yapıldığ tarihte 283 Profesör, 238 Doçent, 591 Yardımcı Doçent, 94 Öğretim Görevlisi, 159 Okutman, 941 Araştırma Görevlisi ve 59 Uzman olmak üzere 2364 kişi görev yapmaktadır. Bu kapsamda, anket uygulanan örnek kütlenin büyüklüğ̈̈;

$$
\mathrm{n}=\frac{\mathrm{N}^{*} \mathrm{P} * \mathrm{Q}^{*} \mathrm{Z}^{2}}{\left((\mathrm{~N}-1)^{*} \mathrm{H}^{2}\right)+\mathrm{P} * \mathrm{Q} * \mathrm{Z}^{2}}
$$

formülünden yararlanarak tespit edilmiştir. Bu formüldeki, $\mathrm{n}=$ Örnek kütle büyüklüğü, $N$ = Ana kütle hacmi (Atatürk Üniversitesi akademisyen sayısı), $\mathrm{P}$ = İnternet bankacılı̆̆ kullanma oranı, $\mathrm{Q}=$ İnternet bankacılığı kullanmama oranı $(1-P), Z=\%(1-\alpha)$ düzeyinde $Z$ test değeri, $\alpha=$ Önem düzeyi, $\mathrm{d}=$ Hata (tolerans) payıdır. Mümkün olduğunca büyük örnekle çalışmak için Atatürk Üniversitesi çalışanların internet bankacılığı kullanma ve kullanmama oranı yaklaşı 0,5 (Kullanma:163 kişi, kullanmama: 143 kişi) olarak alınmış, \% 5 önem düzeyinde $\% 5$ hata payı ile ana kütleyi temsil edecek örnek büyüklüğü,

$$
\mathrm{n}=\frac{2364 * 0,5^{*} 0,5^{*}(1,96)^{2}}{\left.(2364-1) * 0,05^{2}\right)-0,5^{*} 0,5 * 1,96^{2}}
$$

olarak 331 kişi hesaplanmıştır. Araştırmada, hedeflenen minimum örnek büyüklüğü 331'dir. Ancak, eksik ve hatalı doldurulmuş anketlerin olabileceği düşünülerek 350 adet anket sahaya sürülmüştür. Anket uygulaması yapıldıktan sonra eksik ve boş olan anketler ayıklanmış ve 
geriye 308 anket kalmıştır. Bu sayı, hedeflenen 331 sayısından eksiktir ancak, çok fark olmaması yine de güvenilir sonuçlara ulaşılmaktadır. Ayrıca $\alpha$ hatası daha düşük bir seviyeye indirgenerek hesaplamaların daha isabetli kararların verilmesi sağlanmıştır (Oktay ve diğerleri, 2011).

\section{Verilerin Analizi}

Elde edilen verilerin analizi ve araştırmanın kapsamına dâhil edilen katılımcıların genel özelliklerine ilişkin soruların analizi için SPSS 20.0 paket programindan ve bu paket programından elde edilen frekans tablolarından yararlanılmıştır.

Ankete katılan Atatürk Üniversitesinde görev yapan 308 banka müşterisinin demografik özellikleriyle ilgili sayısal bilgiler ve internet bankacılığını kullanma ve kullanmama ile ilgili bulgular Tablo 1'de sunulmuştur. (Tabloda yatık ve daha büyük karakterli olarak kullanilan rakamlar internet bankacılığını kullanan kişilerin sayısıdır.)

Tablo 1:Katılımcıların Demografik Özellikleri ve İnternet Bankacılığını Tercihleri

\begin{tabular}{|l|c|c|l|c|c|}
\hline Cinsiyet & Frekans(f) & Yüzde(\%) & Yaş & Frekans(f) & Yüzde(\%) \\
\hline Erkek & $231 / 137$ & 75.49 & 25 ve az & $17 / 3$ & 5.59 \\
\hline Kadın & $75 / 26$ & 24.51 & $26-35$ & $125 / 65$ & 41.12 \\
\hline Toplam & $\mathbf{3 0 6}$ & $\mathbf{1 0 0}$ & $36-45$ & $102 / 62$ & 33.55 \\
\hline Boş Veri & 2 & & $46-55$ & $46 / 29$ & 15.14 \\
\hline & & & 56 ve fazla & $14 / 2$ & 4.60 \\
\hline & & & Toplam & 304 & $\mathbf{1 0 0}$ \\
\hline & & & Boş Veri & 4 & \\
\hline Medeni Durum & Frekans(f) & Yüzde(\%) & Eş Çalışıor mu? & Frekans(f) & Yüzde(\%) \\
\hline Evli & $236 / 133$ & 77.13 & Evet & $115 / 63$ & 48.8 \\
\hline Bekar & $70 / 30$ & 22.87 & Hayır & $121 / 69$ & 51.2 \\
\hline Toplam & $\mathbf{3 0 6}$ & $\mathbf{1 0 0}$ & Toplam & $\mathbf{2 3 6}$ & $\mathbf{1 0 0}$ \\
\hline Boş Veri & 2 & & Boş Veri & $72 / 1$ & \\
\hline Ev Sahipliği & Frekans(f) & Yüzde(\%) & Araba Sahipliği & Frekans(f) & Yüzde(\%) \\
\hline Evet & $138 / 75$ & 45.85 & Evet & $238 / 140$ & 78.81 \\
\hline Hayır & $163 / 86$ & 54.15 & Hayır & $64 / 21$ & 21.19 \\
\hline Toplam & $\mathbf{3 0 1}$ & $\mathbf{1 0 0}$ & Toplam & 302 & $\mathbf{1 0 0}$ \\
\hline Boş Veri & 7 & & Boş Veri & 6 & \\
\hline $\begin{array}{l}\text { Bilgisayar } \\
\text { Sahipliği }\end{array}$ & Frekans(f) & $\mathbf{Y u ̈ z d e ( \% ) ~}$ & $\begin{array}{l}\text { Temel Bilim } \\
\text { Alanı }\end{array}$ & Frekans(f) & Yüzde(\%) \\
\hline Evet & $273 / 148$ & 89.51 & Sosyal Bilimler & $89 / 34$ & 29.09 \\
\hline
\end{tabular}




\begin{tabular}{|c|c|c|c|c|c|}
\hline Hayır & $32 / 14$ & 10.49 & Fen Bilimleri & $115 / 73$ & 37.58 \\
\hline Toplam & 305 & 100 & Sağlık Bilimleri & $102 / 56$ & 33.33 \\
\hline \multirow[t]{2}{*}{ Boş Veri } & 3 & & Toplam & 306 & 100 \\
\hline & & & Boş Veri & 2 & \\
\hline $\begin{array}{l}\text { Akademik } \\
\text { Unvan }\end{array}$ & Frekans(f) & Yüzde(\%) & $\begin{array}{ll}\text { Ailedeki } & \text { Birey } \\
\text { Sayısı } & \end{array}$ & Frekans(f) & Yüzde(\%) \\
\hline $\begin{array}{l}\text { Okt.-Uzm.- } \\
\text { Öğr.Gör }\end{array}$ & $28 / 7$ & 9.15 & $1-2$ & $55 / 31$ & 18.15 \\
\hline Arşt.Gör. & $95 / 43$ & 31.05 & $3-4$ & $160 / 84$ & 52.81 \\
\hline Yrd.Doç.Dr. & $87 / 50$ & 28.43 & $5-6$ & $81 / 44$ & 26.73 \\
\hline Doç.Dr. & $51 / 33$ & 16.67 & 6 ve fazla & $7 / 3$ & 2.31 \\
\hline Prof.Dr. & $45 / 30$ & 14.70 & Toplam & 303 & 100 \\
\hline Toplam & 306 & 100 & Boş Veri & 5 & \\
\hline Boş Veri & 2 & & & & \\
\hline Gelir & Frekans(f) & Yüzde(\%) & $\begin{array}{l}\text { İnternet } \\
\text { Bankacılığı } \\
\text { Kullanılıyor } \\
\text { mu? }\end{array}$ & Frekans(f) & Yüzde(\%) \\
\hline 1200 'den az & $3 / 0$ & 0.99 & Evet & 163 & 53.27 \\
\hline $1201-1600$ & $28 / 11$ & 9.27 & Hayır & 143 & 46.73 \\
\hline $1601-2000$ & $45 / 19$ & 14.90 & Toplam & 306 & 100 \\
\hline $2001-2400$ & $50 / 30$ & 16.56 & Boş Veri & 2 & \\
\hline $2401-2800$ & $45 / 23$ & 14.90 & & & \\
\hline 2800 'den fazla & $131 / 78$ & 43.38 & & & \\
\hline Toplam & 302 & 100 & & & \\
\hline Boş Veri & 6 & & & & \\
\hline
\end{tabular}

\section{Lojistik Regresyon Modeli}

Sosyal bilimlerde, özellikle sosyo-ekonomik araştırmalarda, araştırıcılar üzerinde çalıştıkları konuda çok değişken olması durumunda değişkenlerin tek tek bağımlı değişken üzerine etkisi yanında, bunların birlikte etkisini de öğrenmek ya da incelemek istemektedirler. İstatistiksel uygulamalarda, çok sayıda bağımsız değişken ile bağımlı değişken arasında bir ilişki kurmak amacıyla Çoklu Regresyon Yöntemi kullanılmaktadır. Çoklu Regresyon Yöntemi'nde bağımlı değişken sürekli veri değerleri almakta ve katsayılar En Küçük Kareler (EKK) tekniği ile bulunmaktadır. 
Ancak, bağımlı değişken nominal ölçekli bir değişken olduğunda EKK Tekniği ile elde edilen tahminler yetersiz kalmaktadır. Diğer bir anlatımla, tahmin edilen varyanslar artık minimum değildir. Çünkü EKK tekniği bağımlı değişkenin normal dağılıma uyduğunu varsaymaktadır. Bağımlı değişken nominal ölçekli olduğunda ise, bu varsayım sağlanamamaktadır. Bağımlı bir modelde, bağımlı değişken nominal ölçekli ise, EKK tekniğine alternatif olarak kullanılabilen teknikler arasında Lojistik Regresyon Analizi yer almaktadır (Albayrak, 2006: 439).

Lojistik Regresyon Analizi, temelde Regresyon Analizi olmakla birlikte bir ayırıcı analiz tekniği olma özelliğini de taşımaktadır. Bu kapsamda, Regresyon Analizi'nden üç önemli farklılı̆̆ı vardır. (Coşkun vd, 2004: 43).

- Regresyon Analizi'nde bağımlı değişken sayısal iken Lojistik Regresyon Analizi'nde kesikli bir değerdir.

- Regresyon Analizi'nde bağımlı değişkenin değeri, Lojistik Regresyon'da ise bağımlı değişkenin alabileceği değerlerden birinin gerçekleşme olasılığı kestirilir.

- Regresyon Analizi'nde bağımsız değişkenlerin çoklu normal dağılım göstermesi koşulu aranırken, Lojistik Regresyon'un uygulanabilmesi için bağımsız değişkenlerin dağılımına ilişkin hiçbir koşul gerekmemektedir.

Araştırmalarda çok zaman bağımlı ve bağımsız değişkenlerin tür ve yapıları birbirine benzememektedir. İncelenen değişkenlerin bazıları hassas ölçekle ölçülmekle beraber, bazıları da iki kategorili verilerden oluşmaktadır. İki farklı değer içeren verilere iki kategorili (Binary) veriler denilmektedir. İki kategorili değişkenler literatürde, $0-1$ değişkenleri olarak da adlandırılmaktadır. Bağımlı değişkenin iki şıklı kategorik veriler olması durumunda, bağımsız değişkenle bağımlı değişken arasındaki sebep-sonuç ilişkisini incelerken İki Değişkenli (Binary) Lojistik Regresyon Analizi kullanılır.

İki Değişkenli (Binary) Lojistik Regresyon Analizi'nin temel amacı, diğer regresyon yöntemlerinde olduğu gibi bağımsız değişkenler ile bağımlı değişken arasındaki nedensellik ilişkisini incelemektir. Başka bir deyişle, amaç en az değişkeni kullanarak en iyi uyumu sağlayacak sonuç değişkeni ve açıklayıcı değişkenler arasındaki ilişkiyi tanımlayan kabul edilebilir modeli kurmaktır. (Ulupınar, 2007: 39).

İki Değişkenli (Binary) Lojistik Regresyon Analizi'nin temeli olasılık oranına dayanır. Olasılık oranı, bir olayın gerçekleşmesi olasılığı ile söz 
konusu olayın gerçekleşmemesi olasılığını karşılaştırır. İki Değişkenli (Binary) Lojistik Regresyon Analizi olasılık oranının doğal logaritması alınarak elde edilir. Olasılık oranının doğal logaritması alınarak elde edilen İki Değişkenli (Binary) Lojistik Regresyon Modeli'nin parametrelerini tahmin ederken en yüksek olabilirlik ve Wald istatistikleri yaygın olarak kullanılmaktadır. (Berenson ve Levine, 1996: 837)

En çok olabilirlik yönteminde, gözlenen veri setini elde etme olasılığını en büyük yapacak şekilde bilinmeyen parametreler için değerler üretilir. Bu yöntemi uygulayabilmek için önce olabilirlik fonksiyonu olarak adlandırılan bir fonksiyonun oluşturulması gerekir. Bu fonksiyon, gözlenen verinin olasılığını bilinmeyen parametrelerin bir fonksiyonu olarak belirtir. $\mathrm{Bu}$ fonksiyonu en büyük yapan değerler, bilinmeyen parametrelerin en çok olabilirlik kestiricileridir. Yani en çok olabilirlik yönteminde, bir olayın olması olasılı̆̆ı en çok yapılmaya çalışııı. (Alpar, 2011)

Wald testi ise, eğim parametresi $\beta 1$ 'in en çok olabilirlik tahmini ile bu tahminin standart hatasını karşılaştırmaya dayanmaktadır.

Olasılık oranının $\mathrm{OR}=\mathrm{P}(\mathrm{Y}) / \mathrm{Q}(\mathrm{Y})$ şeklinde hesaplandığı hatırlanacak olursa, her bir parametrenin $\operatorname{Exp}(\beta)$ değerleri olasılık oranları olarak ele alınırlar. Böylece $\operatorname{Exp}(\beta p), Y$ değişkeninin $X p$ değişkeninin etkisi ile kaç kat daha fazla ya da yüzde kaç oranda fazla gözlenme olasılığına sahip olduğunu belirtir (Özdamar, 1999: 477).

İki Değişkenli(Binary) Lojistik Regresyon Analizi'nde değişken seçimi oldukça önemlidir ve analize bağımsız değişkenin nasıl dâhil edileceği ile ilgilidir. Farklı yöntemler kullanılarak değişkenlerin seçimi yapılabilmektedir. Bu yöntemlerden biri de adımsal seçim yöntemleridir. Çok değişkenli yöntemlerde olduğu gibi adımsal seçim modellerinde bir sonraki aşamada hangi değişkenin modele dâhil edilebileceğine karar verilmektedir. Adımsal seçim yönteminde;

- Değişkenlerin Modele Adım Adım Dâhil Edildiği Yöntemi,

- İleri Seçim Yöntemi (Koşullu),

- İleri Seçim Yöntemi (Olabilirlik Oranı),

- İleri Seçim Yöntemi (Wald),

- Geriye Eleme Yöntemi (Şartlı),

- Geriye Eleme Yöntemi (Olabilirlik Oranı),

- Geriye Eleme Yöntemi (Wald) yaklaşımları kullanılmaktadır (IBM SPSS Regression Models 20.0). 
Çalışmamızda, Tek ve Çoklu İki Değişkenli(Binary) Lojistik Regresyon Analizleri'nde Geriye Eleme Yöntemi(Wald) Yöntemi kullanılmıştır.

Çoklu lojistik regresyon analizi uygulanmadan önce çalışmada kullanılan bağımsız değişkenlerin tek değişkenli analizlerle incelenerek ilgisiz olanların modele alınmaması önerilmektedir. Bu amaçla bağımlı değişkeni ile ilgili bağımsız değişkenler arasında ki-kare, iki ortalama arasındaki farkın önemlilik testi, Mann-Whitney Testi gibi testlerden yararlanılır. Bir diğer yaklaşım ise, her bir bağımsız değişkenle tek değişkenli lojistik regresyon analizi yapmak ve p değerlerini incelemektir. $\mathrm{Bu}$ çerçevede, tek değişkenli analizler sonucunda $\mathrm{p}$ değeri 0,25 'in altında bulunan değişkenlerin çok değişkenli çözümlemede dikkate alınması önerilmektedir (Alpar, 2011). Böylece çok değişkenli çözümlemede daha az sayıda değişken ile ilgilenilir. Özellikle gözlem sayısının az olduğu çalışmalarda, çoklu bağlantı gibi sorunların ortaya çıkması önlenebilir.

\section{Tek Değişkenli Lojistik Regresyon Analizi}

Analizimize başlamadan önce tek değişkenli lojistik regresyon analizi yapılmış ve elde edilen sonuçlar Tablo 2'de sunulmuştur.

Tablo 2:Tek Değişkenli Lojistik Regresyon Analizi Sonuçları

\begin{tabular}{|c|c|c|c|c|c|c|c|c|}
\hline & \multirow{2}{*}{ Katsayı } & \multirow{2}{*}{ S.h. } & \multirow{2}{*}{ Wald } & \multirow{2}{*}{$\mathrm{sd}$} & \multirow{2}{*}{ p. } & \multirow{2}{*}{$\operatorname{Exp}(B)$} & \multicolumn{2}{|c|}{ 95\% EXP(B) Güven Aralı̆ } \\
\hline & & & & & & & Üst & Alt \\
\hline $\operatorname{cins}(1)$ & ,959 & 273 & 12,331 & 1 & ,000 & 2,609 & 1,528 & 4,455 \\
\hline $1 \quad$ Sabit &,- 539 & ,238 & 5,138 & 1 & 023 &, 583 & & \\
\hline Yas & & & 16,081 & 4 & ,003 & & & \\
\hline yas(1) & 1,306 & ,599 & 4,752 & 1 & ,029 & 3,691 & 1,141 & 11,939 \\
\hline yas(2) & 1,674 & 607 & 7,611 & 1 & ,006 & 5,333 & 1,624 & 17,518 \\
\hline 1 yas(3) & 1,713 & 648 & 6,981 & 1 & ,008 & 5,544 & 1,556 & 19,753 \\
\hline yas(4) &,- 613 & ,954 & ,413 & 1 &, 520 &, 542 & ,083 & 3,514 \\
\hline Sabit & $-1,179$ &, 572 & 4,249 & 1 & 039 & ,308 & & \\
\hline medeni(1) &, 531 & ,271 & 3,825 & 1 & 050 & 1,700 & ,999 & 2,893 \\
\hline Constant &,- 223 &, 237 &, 885 & 1 & ,347 &, 800 & & \\
\hline escalıs(1) &,- 119 & ,255 & 218 & 1 & 641 & ,888 &, 539 & 1,463 \\
\hline Sabit & ,283 & 179 & 2,514 & 1 & 113 & 1,327 & & \\
\hline 2 Sabit & ,225 & 127 & 3,123 & 1 & 077 & 1,252 & & \\
\hline $1 \quad \mathrm{ev}(1)$ & ,207 & ,232 & ,794 & 1 &, 373 & 1,230 & ,780 & 1,938 \\
\hline Sabit & ,098 & 156 & 390 & 1 &, 532 & 1,103 & & \\
\hline 2 Sabit & 192 & 115 & 2,767 & 1 & ,096 & 1,212 & & \\
\hline araba(1) & 1,052 & 294 & 12,778 & 1 & ,000 & 2,864 & 1,608 & 5,099 \\
\hline Sabit &,- 647 & ,263 & 6,037 & 1 & 014 &, 524 & & \\
\hline evbilgisay(1) & ,402 &, 370 & 1,181 & 1 & 277 & 1,495 &, 724 & 3,088 \\
\hline Sabit & -182 & ,350 & ,272 & 1 & 602 &, 833 & & \\
\hline Sabit & 176 & 115 & 2,368 & 1 & 124 & 1,193 & & \\
\hline \multirow{4}{*}{$\begin{array}{l}\text { Temelalan } \\
\text { temelalan(1) } \\
\text { temelalan(2) } \\
\text { Sabit }\end{array}$} & & & 13,941 & 2 & , 001 & & & \\
\hline & 1,089 & 292 & 13,928 & 1 & , 000 & 2,970 & 1,677 & 5,261 \\
\hline & ,630 & 294 & 4,584 & 1 & ,032 & 1,878 & 1,055 & 3,345 \\
\hline &,- 434 & 217 & 3,993 & 1 & ,046 & 648 & & \\
\hline \multirow{3}{*}{$\begin{array}{ll}1 & \text { Unvanı } \\
& \text { unvanı(1) } \\
& \text { unvanı(2) }\end{array}$} & & & 15,878 & 4 & ,003 & & & \\
\hline & ,993 & 482 & 4,240 & 1 & ,039 & 2,700 & 1,049 & 6,950 \\
\hline & 1,514 & 488 & 9,629 & 1 & ,002 & 4,543 & 1,746 & 11,817 \\
\hline
\end{tabular}




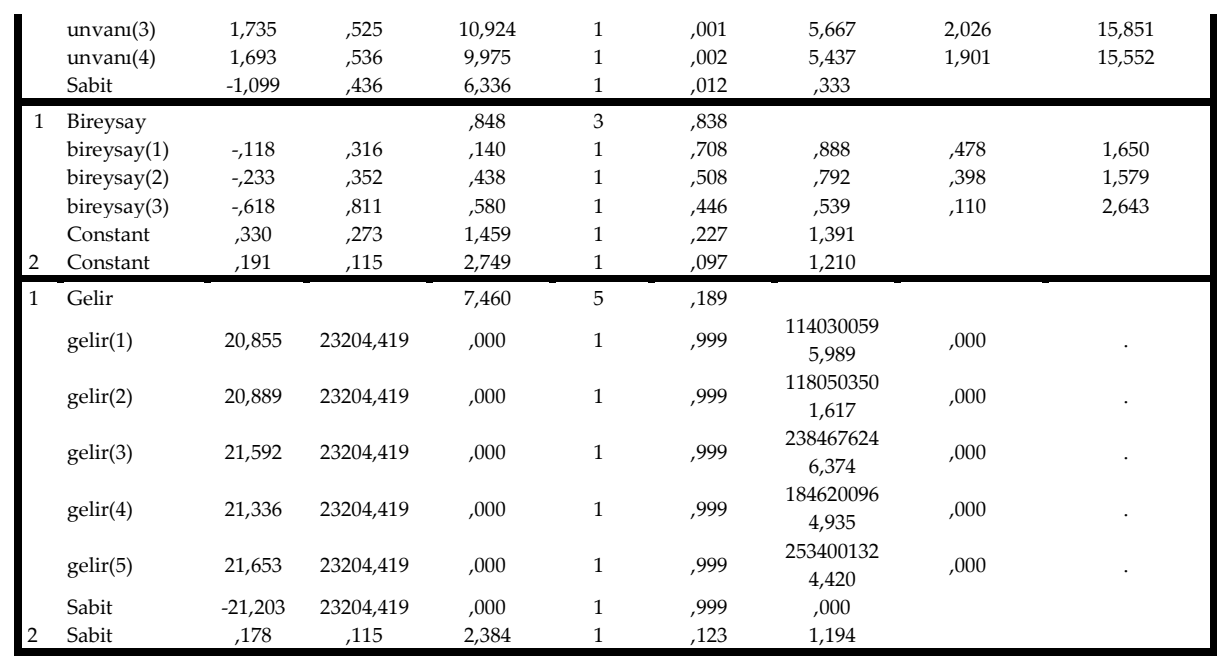

Bu sonuçlara göre;

$\checkmark \quad$ Eşin çalışma durumu, ev sahipliği, evde bilgisayar sahipliği ve ailedeki birey sayısı değişkenlerinin $p$ değerleri 0,25 'den büyük, diğerlerinin ise küçüktür.

$\checkmark \quad \% 95$ anlamlılık düzeyinde $\mathrm{p}$ değeri $0,25^{\prime}$ den büyük olan değişkenlerin EXP(B) güven aralıkları hepsi 1'i kapsamakta, diğerlerinin ise 1'i kapsamamaktadır.

$\checkmark \quad$ Gelir değişkeninin katsayıları ve standart hataları çok büyük çıkmış ve $\mathrm{p}$ değerleri 1 'e yakındır. Bu durum gelir değişkeninin kukla değişkenleri arasında tam bağlantı sorununun olduğunu gösterir.

Sonuç olarak, Tek Değişkenli Lojistik Regresyon Analizi sonucunda, 6 adet değişkenin anlamlı olduğu sonucuna varılmış ve Çoklu Lojistik Regresyon Analizine cinsiyet $(\mathrm{p}=0.000)$, yaş( $\mathrm{p}=0.003)$, medeni durum( $\mathrm{p}=0.05)$, araba sahipliği $(\mathrm{p}=0.000)$, temel bilim $\operatorname{alanı}(\mathrm{p}=0.001)$ ve akademik unvan( $\mathrm{p}=0.003)$ değişkenleri alınmıştır.

\section{Çoklu Lojistik Regresyon Analizi}

Tablo 3'de, SPSS sonuçlarından ilk olarak çoklu lojistik regresyon analizine dâhil edilen ve edilmeyen birim sayıları ile ilgili işlem özeti verilmiştir. Başlangıçta, elimizde toplam olarak 308 (\% 100) kayıt bulunmaktadır. Ancak, eksik veri olmasından dolayı bu kayıtlardan 5 adedi $(\%$ 1,6) işleme tabi tutulmamıştır. Dolayısıyla bütün işlemler 303 kayıt $(\% 98,4)$ üzerinden yapılacaktır. 
Tablo 3:İșlem Özeti

\begin{tabular}{|l|r|r|}
\hline \multicolumn{1}{|c|}{ Durum } & N & Yüzdesi \\
\hline Analize dâhil edilenler & 303 & 98,4 \\
Analize dâhil & 5 & 1,6 \\
edilmeyenler & 308 & 100,0 \\
Toplam Sayı & & \\
\hline
\end{tabular}

Bağımlı değişken olan internet bankacılığını kullananlar kişiler "2" değeri ile kullanmayanlar ise, "1" değeri ile kodlanmıştır. Ancak, yorumlamada kolaylık sağlanması için referans grubu olarak bu değerlen SPSS paket programında bu şıklar sırasıyla " 1 " ve "0" olarak kodlanma yoluna gidilmiştir. Ayrıca, bağımsız değerlerin hepsi ya ikili ya da çok kategorili değişken şeklindedir. Bunlarla ilgili SPSS'deki kodlanma durumu ise Tablo 4'de sunulmuştur. Kategorik verilerde referans grubu bazılarında ilk şık bazılarında ise son şık alınmış ve SPSS programında "indicator/first veya last" seçilmiştir. Ayrıca, Tablo-4'de her şıkkın frekans dağılımı da gözükmektedir.

Tablo 4:Kategorik Değişkenlerin Kodlanması

\begin{tabular}{|c|c|c|c|c|c|c|}
\hline & \multirow[t]{2}{*}{ Frekans } & \multicolumn{4}{|c|}{ Parametre Kodu } \\
\hline & & & (1) & (2) & (3) & (4) \\
\hline \multirow{6}{*}{$\begin{array}{l}\text { Akademik unvanınız } \\
\text { hangisidir? }\end{array}$} & $\begin{array}{l}\text { Okt-Uzm- } \\
\text { Öğgr.Gör. }\end{array}$ & 28 & ,000 & ,000 & ,000 & ,000 \\
\hline & Arş.Gör. & 91 & 1,000 & ,000 & 000 & 000 \\
\hline & Y.Doç.Dr. & 88 & ,000 & 1,000 & 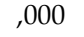 & 000 \\
\hline & Doç.Dr. & 51 & ,000 & ,000 & 1,000 & 000 \\
\hline & Prof.Dr. & 45 & 000 & ,000 & ,000 & 1,000 \\
\hline & 25 ve $A z$ & 17 & , 000 & 000 & 000 & 000 \\
\hline \multirow{4}{*}{ Yaşınız? } & 26 ile 35 & 124 & 1,000 & ,000 & , 000 & ,000 \\
\hline & 36 ile 45 & 102 & 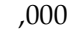 & 1,000 & 000 & ,000 \\
\hline & 46 ile 55 & 46 & 000 & ,000 & 1,000 & ,000 \\
\hline & 56 ve Üstü & 14 & ,000 & ,000 & ,000 & 1,000 \\
\hline \multirow{3}{*}{$\begin{array}{l}\text { Hangi temel bilim } \\
\text { alanında } \\
\text { çalışıyorsunuz? }\end{array}$} & Sosyal Bilimler & 89 & ,000 & 000 & & \\
\hline & Fen Bilimleri & 113 & 1,000 & 000 & & \\
\hline & Sağllk Bilimleri & 101 & , 000 - - r & 1,000 & & \\
\hline \multirow{2}{*}{ Medeni durumunuz? } & Evli & 236 & 1,000 & & & \\
\hline & Bekâr & 67 & ,000 & & & \\
\hline \multirow{3}{*}{$\begin{array}{l}\text { Kendinize ait bir } \\
\text { arabanız var mı? }\end{array}$} & Evet & 240 & 1,000 & & & \\
\hline & Hayır & 63 & ,000 & & & \\
\hline & Bay & 230 & 1,000 & & & \\
\hline Cinsiyetiniz? & Bayan & 73 & , 000 & & & \\
\hline
\end{tabular}




\section{Bağımsız Değişkenler Arasında Çoklu Bağlantı Sorununun İncelenmesi}

Lojistik regresyon yönteminde çok değişkenli normallik dışında başka varsayım aranmasa da, kestirimlerin sağlıklı ve isabetli yapılabilmesi için değişkenlerin arasında kuvvetli bir ilişkinin olmaması önem arz etmektedir.

Lojistik regresyon analizinde iki ya da daha fazla bağımsız değişkenler arasındaki korelasyonlar yüksek olduğunda çoklu bağlantı sorunu ortaya çıkmaktadır. Korelasyon katsayısı 1 olduğunda çoklu bağlantı tam çoklu bağlantı olarak adlandırılmaktadır.

Uygulamalarda tam çoklu bağlantı sorunuyla çok fazla karşılaşılmamaktadır. Ancak karşılaşılması durumunda da regresyon katsayıları kestirilememektedir. Başarılı olunduğu durumlarda, katsayılar yansız olmakla beraber standart hataları olduğunca büyük kestirilir. Genelde düşük düzeydeki çoklu bağlantı sorun yaratmazken yüksek düzeydeki çoklu bağlantı bazı durumlarda model için önemli bir değişken istatistik bakımından önemsiz bulunarak model dışında kalmaktadır. Ayrıca katsayılarda çoklu bağlantı nedeniyle aşırı büyük kestirilme durumundadır.

Doğrusal regresyon yönteminde çoklu bağlantı durumu tolerans veya varyans şişirme değerleri yardımıyla hatta başka istatistiklerle de incelenebilmektedir. Ancak lojistik regresyon yönteminde bunlara benzer istatistikler ve teknikler bulunmamaktadır. Bazı yazarlar tarafından doğrusal regresyon yönteminde kullanılan tekniklerin kullanılmasını önerirken, başka yazarlar ise çoklu bağlantı olan değişkenlerden sadece birisinin veya bu değişkenlerden oluşturulacak yeni değişkenin modele alınması gibi yöntemlerden yararlanılması önerilmektedir.

Çalışmamızda Tablo 5’deki bağımsız değişkenler arasındaki korelasyon matrisi incelendiğinde bazı değişkenler arasında yüksek korelasyon tespit edilmiştir. Ancak, çok fazla yüksek olmamasından dolayı bu durum fazla önemsenmeyecektir. 
Tablo 5:Bağımsız Değişkenler Arasındaki Korelasyon Matrisi

\begin{tabular}{|c|c|c|c|c|c|c|c|c|c|c|c|c|c|c|}
\hline & 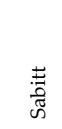 & $\begin{array}{l}\widehat{\vec{y}} \\
. \bar{\theta}\end{array}$ & 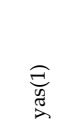 & 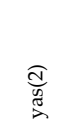 & 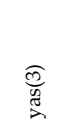 & 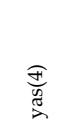 & 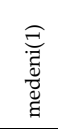 & 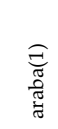 & 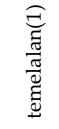 & 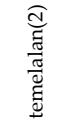 & 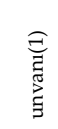 & 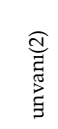 & 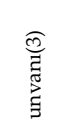 & 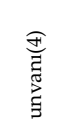 \\
\hline Sabit & 1,000 & -287 & -659 & -624 & - -582 & -432 & 078 & -182 & 195 & -224 & -512 & -351 & -271 &,- 232 \\
\hline $\operatorname{cins}(1)$ &,- 287 & 1,000 & ,038 & 017 & ,022 & -022 & -237 & -006 & ,076 & 117 & 112 & ,027 & -026 & - \\
\hline yas(1) & -659 & 038 & 1,000 & 681 & 700 & 617 & -261 & -,049 & -010 & 013 & -,046 & -106 &,- 081 &,- 064 \\
\hline yas(2) & -624 & ,017 & 681 & 1,000 & 763 & ,661 & -311 & - & ,028 & , 030 & ,022 & -184 & -201 & -180 \\
\hline yas(3) &,- 582 & ,022 & ,700 & 763 & 1,000 & ,658 & -307 & -025 & ,078 & ,082 & 027 & -,171 & 198 & -317 \\
\hline yas(4) &,- 432 &,- 022 & 617 & 661 & 658 & 1,000 & -211 &,- 032 & 073 & 053 & 005 & -165 & -131 &,- 251 \\
\hline medeni(1) & 078 & -237 &,- 261 &,- 311 & -307 & -211 & 1,000 &,- 223 & 017 & -,116 &,- 026 &,- 060 &,- 048 &,- 048 \\
\hline $\operatorname{araba(1)}$ &,- 182 & -,006 &,- 049 & -037 & -,025 &,- 032 &,- 223 & 1,000 &,- 036 & -077 & ,039 &,- 064 & -119 & -124 \\
\hline $\begin{array}{l}\text { Temelalan } \\
\text { (1) }\end{array}$ &,- 195 & 076 & -010 & ,028 & 078 & 073 & 017 &,- 036 & 1,000 & ,553 & -,075 &,- 085 & -157 &,- 126 \\
\hline $\begin{array}{l}\text { Temelalan } \\
\text { (2) }\end{array}$ &,- 224 & 117 & , 013 & , 030 & ,082 & 053 & -116 &,- 077 & ,553 & 1,000 &,- 038 &, 060 & , 022 & ,002 \\
\hline Unvanı (1) &,- 512 & 112 & -046 & ,022 & , 027 & 005 & -026 & 039 & -075 & -038 & 1,000 & 726 & 640 &, 552 \\
\hline Unvanı(2) &,- 351 & ,027 & -106 & -184 & -171 & 165 &,- 060 &,- 064 & -,085 & , 060 & ,726 & 1,000 & ,768 & 707 \\
\hline Unvanı(3) &,- 271 &,- 026 & -081 & -201 & 198 & -131 & -,048 & -119 & -157 & ,022 & ,640 & ,768 & 1,000 & ,696 \\
\hline Unvanı(4) &,- 232 &,- 006 &,- 064 & 180 & - &,- 251 & -048 & - 124 & -126 & ,002 &, 552 & ,707 & 696 & 1,000 \\
\hline Sabit & 1,000 &,- 276 & -663 & -631 & -,587 & -426 & & - 170 & -198 年 & -218 &,- 511 & -348 & -268 &,- 228 \\
\hline $\operatorname{cins}(1)$ &,- 276 & 1,000 &,- 026 &,- 064 & -,057 &,- 077 & &,- 061 & ,085 & ,093 & ,106 & ,012 &,- 040 &,- 020 \\
\hline yas(1) &,- 663 &,- 026 & 1,000 & 671 & ,783 &, 594 & &,- 116 & -,007 &,- 020 &,- 054 & -126 & -,096 &,- 078 \\
\hline yas(2) &,- 631 &,- 064 & ,671 & 1,000 & ,649 & ,640 & &,- 116 & ,034 &,- 008 & ,013 &,- 215 & -230 & -206 \\
\hline yas(3) &,- 587 & -057 & ,783 & 649 & 1,000 & ,637 & &,- 101 & ,087 & ,048 & ,020 &,- 200 &,- 224 &,- 350 \\
\hline yas(4) &,- 426 &,- 077 &, 594 & ,640 & ,637 & 1,000 & &,- 085 & ,078 & ,029 & ,000 & -182 & -145 & -267 \\
\hline $\operatorname{araba}(1)$ & -170 &,- 061 & -116 & -116 & 101 &,- 085 & & 1,000 &,- 030 & -103 & ,033 &,- 081 & 133 & 139 \\
\hline $\begin{array}{l}\text { Temelalan } \\
\text { (1) }\end{array}$ &,- 198 & ,085 & -007 & ,034 & ,087 & , 078 & & - & 1,000 &, 560 & -,076 &,- 085 & -157 & -126 \\
\hline $\begin{array}{l}\text { Temelalan } \\
\text { (2) }\end{array}$ &,- 218 & ,093 &,- 020 & -008 & ,048 &, 029 & &,- 103 & ,560 & 1,000 &,- 041 & ,053 & , 016 &,- 005 \\
\hline unvanı(1) &,- 511 & ,106 &,- 054 & ,013 & , 020 & ,000 & & ,033 &,- 076 &,- 041 & 1,000 & ,626 & ,640 &, 552 \\
\hline unvani(2) &,- 348 & ,012 & -126 & -215 & -200 & -182 & &,- 081 & -,085 & ,053 & ,626 & 1,000 & ,568 & 706 \\
\hline unvanı(3) &,- 268 &,- 040 &,- 096 &,- 230 &,- 224 & -145 & & -133 & -157 & ,016 & 640 &, 568 & 1,000 & 695 \\
\hline unvanı(4) &,- 228 &,- 020 & -078 & -206 &,- 350 &,- 267 & & -139 & -126 &,- 005 & ,552 & ,706 & 695 & 1,000 \\
\hline Sabit & 1,000 &,- 272 & -602 &,- 546 & ,608 & -,498 & & -151 &,- 253 & -275 & & & & \\
\hline $\operatorname{cins}(1)$ &,- 272 & 1,000 &,- 027 & -115 & 119 & -113 & & -,086 & 086 & ,121 & & & & \\
\hline yas(1) &,- 602 &,- 027 & 1,000 & 899 & 844 &, 598 & & -157 & -037 &,- 024 & & & & \\
\hline yas(2) &,- 546 & -,115 & ,899 & 1,000 & ,850 & ,606 & &,- 229 &,- 019 & ,013 & & & & \\
\hline yas(3) &,- 608 &,- 119 & 844 &, 850 & 1,000 & ,576 & & -238 & ,032 & ,065 & & & & \\
\hline yas(4) &,- 498 & -113 &, 598 & ,606 &, 576 & 1,000 & & -168 & ,042 & , 047 & & & & \\
\hline $\operatorname{araba}(1)$ &,- 151 & -086 & -157 &,- 229 & -238 & 168 & & 1,000 &,- 067 & -097 & & & & \\
\hline $\begin{array}{l}\text { Temelalan } \\
\text { (1) }\end{array}$ &,- 253 & ,086 & -037 & -019 & 032 & ,042 & &,- 067 & 1,000 & ,571 & & & & \\
\hline $\begin{array}{l}\text { Temelalan } \\
\text { (2) }\end{array}$ &,- 275 & ,121 & -024 & 013 & 065 & 047 & & -,097 & ,571 & 1,000 & & & & \\
\hline
\end{tabular}

Modelin Oluşturulması

Model oluşturmada işlemlerinde temel amaç, modelde bulunması gereken faktörlerin ya da değişkenlerin belirlenmesidir. Bu kapsamda, çalışma da, mevcut değişkenler arasında en uygun değişkenleri seçmekte bizim amacımız olacaktır. 
Uygulamada sadece bir tane en iyi model yerine çok sayıda iyi modelin olması olasıdır ve istatistiksel olarak algoritmalardan hiçbirisi en iyi modeli sağlamayı garanti edememektedir. Bu nedenle, olası modellerin geniş bir aralıkta değerlendirilmesi istenir (Alpar, 2011).

Model seçim stratejisi çalışmanın amacına bağlı olarak düzenlenebilir. Bazı uygulamalarda, elde edilen pek çok değişkenden hangilerinin sonuç değişkenini etkilediği belirlenmek istenebilir (Alpar, 2011). Buradaki amaç hangi değişken ya da değişkenlerin bağımlı değişkeni etkilediğini araştırmaktır.

Modelin oluşturulma yöntemi seçilirken açıklayıcı değişken sayısına bakılır. Eğer açıklayıcı değişken sayısı fazla ise olası modellerin sayısı da fazla olacaktır. Bu durumda çoğu istatistiki yazılımlarda değişken seçiminde adımsal yöntemler mevcuttur. Bu yöntemler, ileriye dönük seçim yöntemi, geriye dönük seçim yöntemi ve bu iki yöntemin karışımı olan adım adım regresyon yöntemidir.

Çalışmamızda kullanılan yöntem geriye dönük adımsal yöntem olup değişkenlerin çıkarılmasında kullanılan $\alpha$ anlamlılık düzeyi 0,1'dir. Modeli genel olarak test etmede ise kullanılacak $\alpha$ anlamlılık düzeyi ise $0,05^{\prime}$ dir.

Geriye dönük adımsal eleme analiz sonuçları Tablo 6'da sunulmuştur.

Tablo 6:Geriye Dönük Adımsal Eleme Analiz Sonuçları

\begin{tabular}{|c|c|c|c|c|c|c|c|c|c|}
\hline & \multirow[t]{2}{*}{ Katsayı } & \multirow[t]{2}{*}{ S.h. } & \multirow[t]{2}{*}{ Wald } & \multirow[t]{2}{*}{ S.d. } & \multirow[t]{2}{*}{$\mathrm{P}$} & \multirow[t]{2}{*}{$\operatorname{Exp}(B)$} & \multicolumn{2}{|c|}{$\begin{array}{c}95 \% \text { EXP(B) Güven } \\
\text { Aralığ1 } \\
\end{array}$} \\
\hline & & & & & & & & Alt & Üst \\
\hline \multirow{18}{*}{ Adım 1} & $\operatorname{cins}(1)$ &, 927 & 326 & 8,057 & 1 & ,005 & 2,526 & 1,332 & 4,789 \\
\hline & Yas & & & 10,284 & 4 & 036 & & & \\
\hline & yas(1) & 697 & 692 & 1,014 & 1 & ,314 & 2,008 & ,517 & 7,802 \\
\hline & yas(2) &, 505 & ,773 & ,426 & 1 &, 514 & 1,656 & ,364 & 7,542 \\
\hline & yas(3) & ,395 & 861 & 210 & 1 & 646 & 1,484 & 275 & 8,020 \\
\hline & yas(4) & $-1,931$ & 1,113 & 3,010 & 1 & 083 & 145 & ,016 & 1,285 \\
\hline & medeni(1) &,- 270 & ,383 & ,497 & 1 & ,481 & ,763 & ,360 & 1,617 \\
\hline & $\operatorname{araba}(1)$ & 687 & 356 & 3,722 & 1 & ,054 & 1,988 & ,989 & 3,997 \\
\hline & temelalan & & & 6,873 & 2 & ,032 & & & \\
\hline & temelalan(1) & ,825 & 325 & 6,447 & 1 & 011 & 2,281 & 1,207 & 4,312 \\
\hline & temelalan(2) & ,648 & ,333 & 3,791 & 1 & ,052 & 1,912 & ,996 & 3,673 \\
\hline & unvanı & & & 6,902 & 4 & 141 & & & \\
\hline & unvanı(1) & ,830 & ,526 & 2,491 & 1 & 115, & 2,293 & ,818 & 6,430 \\
\hline & unvanı(2) & 1,326 &, 547 & 5,869 & 1 & ,015 & 3,764 & 1,288 & 11,000 \\
\hline & unvanı(3) & 1,131 & 603 & 3,525 & 1 & 060 & 3,100 & 952 & 10,098 \\
\hline & unvanı(4) & 1,600 & 676 & 5,606 & 1 & 018 & 4,955 & 1,317 & 18,637 \\
\hline & Sabit & $-2,893$ & 816 & 12,579 & 1 & , 000 & ,055 & & \\
\hline & $\operatorname{cins}(1)$ & ,874 & 316 & 7,626 & 1 & 006 & 2,395 & 1,289 & 4,453 \\
\hline
\end{tabular}




\begin{tabular}{|c|c|c|c|c|c|c|c|c|c|}
\hline & $\begin{array}{l}\text { Yas } \\
\operatorname{yas}(1)\end{array}$ & 569 & 667 & $\begin{array}{c}10,109 \\
, 727\end{array}$ & $\begin{array}{l}4 \\
1\end{array}$ & $\begin{array}{l}, 039 \\
, 394\end{array}$ & 1,767 & ,478 & 6,533 \\
\hline & yas(2) & ,333 & ,734 & ,206 & 1 & 650 & 1,395 & ,331 & 5,883 \\
\hline & yas(3) & ,207 & 818 & ,064 & 1 & 800 & 1,230 & 247 & 6,112 \\
\hline & yas(4) & $-2,100$ & 1,088 & 3,727 & 1 & 054 & 122 & 015 & 1,033 \\
\hline & $\operatorname{araba}(1)$ & 633 & 347 & 3,322 & 1 & 068 & 1,883 & 953 & 3,719 \\
\hline & temelalan & & & 6,818 & 2 & 033 & & & \\
\hline & temelalan(1) & ,830 & ,325 & 6,519 & 1 & 011 & 2,294 & 1,213 & 4,338 \\
\hline & temelalan(2) & 622 & ,330 & 3,547 & 1 & ,060 & 1,863 & 975 & 3,561 \\
\hline & unvanı & & & 6,732 & 4 & 151 & & & \\
\hline & unvanı(1) & ,822 & ,525 & 2,457 & 1 & 117 & 2,275 & 814 & 6,362 \\
\hline & unvanı(2) & 1,305 &, 546 & 5,717 & 1 & ,017 & 3,689 & 1,265 & 10,754 \\
\hline & unvanı(3) & 1,113 & 602 & 3,417 & 1 & ,065 & 3,044 & ,935 & 9,911 \\
\hline & unvanı(4) & 1,580 & 675 & 5,476 & 1 & ,019 & 4,853 & 1,292 & 18,222 \\
\hline & Sabit & $-2,852$ & ,811 & 12,364 & 1 & , 000 & ,058 & & \\
\hline & $\operatorname{cins}(1)$ & ,903 & ,309 & 8,558 & 1 & ,003 & 2,466 & 1,347 & 4,515 \\
\hline & Yas & & & 9,070 & 4 & 059 & & & \\
\hline & yas(1) & 792 & 649 & 1,486 & 1 & 223 & 2,207 & 618 & 7,881 \\
\hline & yas(2) & 808 & 672 & 1,448 & 1 & ,229 & 2,244 & 602 & 8,368 \\
\hline & yas(3) & ,885 & ,717 & 1,524 & 1 & ,217 & 2,423 &, 594 & 9,879 \\
\hline Adım 3 & yas(4) & $-1,355$ & 1,011 & 1,796 & 1 & 180 & ,258 & ,036 & 1,872 \\
\hline & $\operatorname{araba}(1)$ & ,766 & 334 & 5,265 & 1 & 022 & 2,152 & 1,118 & 4,140 \\
\hline & temelalan & & & 8,806 & 2 & ,012 & & & \\
\hline & temelalan(1) & ,939 & 317 & 8,760 & 1 & ,003 & 2,558 & 1,373 & 4,764 \\
\hline & temelalan(2) & 602 & ,323 & 3,483 & 1 & 062 & 1,826 & 970 & 3,435 \\
\hline & Sabit & $-2,350$ & 677 & 12,042 & 1 & ,001 & ,095 & & \\
\hline
\end{tabular}

3. adım sonunda modelde cinsiyet $(p=0,003<0,1)$, yas $(p=0,059<0,1)$, araba sahipliği $(p=0,022<0,1)$ ve temel alan $(p=0,012<0,1)$ değişkenleri kalmıştır. Sonuç model için lojistik regresyon modeli aşağıdaki gibi yazilacaktır.

$\pi(x)=\operatorname{Pr}($ Evet $($ Internet Bankacılığ Kullanma $) / x))=$

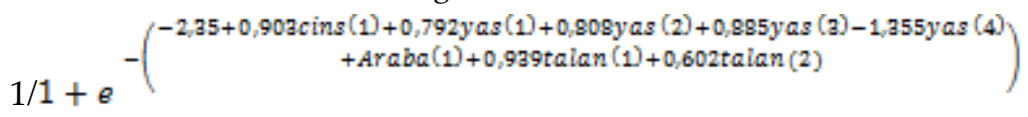

Bu model kullanılarak Atatürk Üniversitesinde görev yapan bir akademisyenin internet bankacılığını kullanıp veya kullanmayacağı kestirilebilinir. Modeldeki bütün değişkenler kategorik değişken olarak tanımlanmıştır.(SPSS çıktısında Indicator/First kontrastı kullanılması neticesinde Tablo 4'de Kategorik değiş̧kenlerin kodlanması başlıklı tabloda değiş̧kenlerin alacağı değerler görülmektedir.)

\section{Model Uyum İyiliğinin Değerlendirilmesi}

Oluşturulan modelin uyum iyiliğini değerlendirmek için sıklıkla Pearson ki-kare testi, parametrelerin anlamlılığının sınanmasında kullanılan Omnibus ve Wald istatistikleri, Hosmer-Lemeshow Testi, doğru sınıflama oranları gibi yöntemler kullanılmaktadır.

Literatürde parametrelerin anlamlılığının sınanmasında kullanılan birçok test çeşidi olmasına rağmen Omnibus ve Wald istatistikleri bu testlerden en çok kullanılanıdır. Bu testlerden çalışmamızda modelin 
uyumluluğu ilk olarak Wald İstatistiği ve müteakiben Omninus Tesyi açısından incelenecektir.

Wald testi, eğim parametresi $\beta 1$ 'in en çok olabilirlik tahmini ile bu tahminin standart hatasını karşılaştırmaya dayanmaktadır. B1'nın standart hatası, kovaryans matrisindeki köşegen elemanlarının kareköklerinin alınmasıyla elde edilmektedir. Lojistik regresyon modeli için bu test istatistiği aşağıdaki biçimde tanımlanabilir:

$$
W=\frac{\hat{\beta}_{1}}{S E\left(\hat{\beta}_{1}\right)}
$$

Eğim parametresini gösteren $\mathrm{H}_{1}=0$ hipotezi için $\mathrm{W}$ istatistiği standart normal dağılım göstermektedir. Wald testinin başka bir açıdan da değerlendirmek mümkündür. Normal rassal bir değişkenin karesinin alınması 1 serbestlik dereceli bir ki-kare rassal değişkenine eşit olacağından, Wald istatistiği aşağıdaki biçimde de ifade edilebilir (Alpar, 2011: 626).

$$
W^{2}=\left(\frac{\hat{\beta}_{1}}{S E\left(\hat{\beta}_{1}\right)}\right)^{2}
$$

Geriye dönük adımsal yönteminin başlangıç aşamasında, tüm değişkenler modele alınır ve bağımlı değişkenle ilişkisi en az olan değişkenden başlanarak değişkenler modelden çıkartılır. Çalışmamızda, modele giren değişkenler sırasıyla cinsiyet, yaş, medeni durum, araba sahipliği, temel alan ve akademik unvan değişkenleridir.

Geriye dönük adımsal yönteminde değişkenin modelden çıkartıldığında modelin her aşamada anlamlılığını test eden Omnibus Testleri Tablo 7'de gösterilmiştir. Değişkenler modelden çıkartılırken Wald İstatistiği değerleri kullanılmıştır.

Geriye dönük adımsal eleme yönteminde değişkenlerin modelden çıkarılmasında kullanılacak hipotez ve karşı hipotez aşağıda sunulmuştur.

Adımsal ki-kare ile ilgili hipotez testleri;

“Ho:Modelden Çıkarılan Değişkenin Modele Katkısı Yoktur.

Hı:Modelden Çıkarılan Değişkenin Modele Katkısı Vardır." şeklinde kurulur.

Birinci adımda, modele katkısı en az olan medeni değişkeni modelden çıkartıldığında model ki-kare 53,561 olarak elde edilmekte ve 
anlamlı olduğunu ortaya koymaktadır $(53,561>21,026, p<0,05)$. Adım ki-kare değeri (Tablo 7:54,063-53,561=0,502, $p=0,479>0,1$ ) Ho kabul edilir ve medeni değişkeninin çıkartılmasının modelde anlamlı bir değişime neden olmadığını belirtmektedir.

İkinci adımda, katkısı az olan unvan değişkeni modelden çıkartılarak adımsal işlemlere devam edilir. Modele katkısı en az olan unvan değişkeni modelden çıkartıldığında model ki-kare 46,378 değerini elde ederiz ve 46,378>15,507 p ( $s d: 8, \alpha: 0,05$ ) ile $\mathrm{H}_{0}$ reddedilir. Model anlamlıdır. Ayrıca, adım ki-kare değeri (Tablo 7: 53,561-46,378=7,182, $p=0,127>0,1$ ) unvan değişkeninin çıkartılmasının modelde anlamlı bir değişime neden olmadığını belirtmektedir.

Üçüncü ve son adımda ise, değişkenlere ait Wald istatistiği $p$ değerleri 0,1 anlamlılık düzeyinden küçük olması nedeniyle geriye dönük adımsal analiz yöntemine son verilir ve Model ki-kare değerinin 46,378 $>15,507$ p(sd: 8, $\alpha$ : 0,05) ile $\mathrm{H}_{0}$ reddedilir. Elde edilen en son model anlamlıdır.

Katsayıların yorumunu katsayıların sıfıra eşit olup olmadığı şeklinde hipotezler kurulduğunda ise müteakip cümlelerde olduğu gibi ifade edebiliriz.

Model ki-kare ile ilgili hipotez testleri;

"Ho: Model anlamsizdir. $(\mathrm{B} 1=\mathrm{B} 2=\ldots \ldots . .=\mathrm{Bk}=0)$

$\mathrm{H}_{1}$ : Model anlamlıdır. $(\mathrm{B} 1 \neq \mathrm{B} 2 \neq \ldots \neq \mathrm{Bk} \neq 0)$ şeklinde kurulur.

Tablo 7'de her adımda modelin anlamlılığını test eden Omnibüs testleri ve ayrıca Tablo 6'da verilere uygulanan geriye dönük adımsal yöntemin 3. adımında elde edilen Wald istatistiği değerleri görülmektedir. Omnibüs testlerinde geçen model ki-kare istatistiği, lojistik regresyon modelini genel olarak test etmektedir. Bağımsız değişkenlerden hiçbirinin bağımlı üstünlük oranıyla anlamlı doğrusal bir ilişki göstermediğini ileri süren sıfır hipotezini test etmektedir. Bir başka deyişle bu istatistik, sabit terimin dışındaki tüm logit katsayılarının sıfıra eşit olup olmadığını sınamaktadır. Model Ki-Kare istatistiği, incelenen modelin parametre sayısı ile yalnız sabit terimli modelin parametreleri arasındaki farka eşit bir serbestlik derecesi ile Ki-Kare dağılımına uymaktadır.

Katsayılar incelendiğinde Wald istatistiğine ait $\mathrm{p}$ değerleri ve Tablo 7'de Omnibus Testindeki her adımda elde edilen modellerin parametrelerinin model Ki-kare değerleri anlamlılık düzeyimiz olan 0,05'den küçük olasından dolayı her iki test istatistiğine göre kestirilen katsayıların anlamlı olduğuna karar veririz. (Model ki-kare: 46,378 sd.:8 
$p=0.000$ ve 3 Adımda kestirilen katsayıların Wald değerleri, sd.leri ve $p$ değerleri Tablo 6'da yer almaktadır.).

Tablo 7:Model Katsayılarının Omnibus Testleri

\begin{tabular}{|rl|r|r|r|}
\hline & & $\chi 2$ & sd & \multicolumn{2}{|c|}{$\mathrm{p}$} \\
\hline \multirow{3}{*}{ Adım 1 } & Adım & 54,063 & 13 &, 000 \\
& Blok & 54,063 & 13 &, 000 \\
& Model & 54,063 & 13 &, 000 \\
\multirow{3}{*}{ Adım 2 } & Adım &,- 502 & 1 &, 479 \\
& Blok & 53,561 & 12 &, 000 \\
& Model & 53,561 & 12 &, 000 \\
& Adım & $-7,182$ & 4 &, 127 \\
Adım 3 & Blok & 46,378 & 8 &, 000 \\
& Model & 46,378 & 8 &, 000 \\
\hline
\end{tabular}

Tablo 8:Modelden Çıkartılan Değișkenler

\begin{tabular}{|lll|r|r|r|}
\hline & & Skor & sd & \multicolumn{1}{c|}{$\mathrm{p}$} \\
\hline \multirow{2}{*}{ Adım 2a } & & Değişken medeni(1) &, 498 & 1 &, 480 \\
& Toplam İstatistik &, 498 & 1 &, 480 \\
& & Unvanı & 7,084 & 4 &, 132 \\
& & unvanı(1) &, 050 & 1 &, 822 \\
& & 1,187 & 1 &, 276 \\
Adım 3b & Değişkenler & unvanı(2) &, 061 & 1 &, 804 \\
& & unvanı(3) & 1,012 & 1 &, 314 \\
& & unvani(4) &, 316 & 1 &, 574 \\
& & medeni(1) & 7,574 & 5 &, 181 \\
\hline
\end{tabular}

a. Adım 1'de çıkartılan değişken: medeni.

b. Adım 2'de çıkartılan değişken: unvanı.

Modelin uyum iyiliğinin değerlendirilmesinde kullanılan yöntemlerden diğeri Tablo 9'da yer alan sinıflandırma tablosudur. Lojistik regresyon analizi sonucunda elde edilen olasılık değerleri belirlenen kesim noktasina (cutoff value) göre sinıflanarak her bir bireyin 0 veya 1 değerlerinden hangisini alacağı kestirilir. Genellikle kesim noktası olarak 0,5 değeri alınır. Lojistik regresyon analizinden elde edilen olasılık değeri 0,5'in üzerinde olduğunda kişi 1 . gruba, 0,5'in altında olduğu durumlarda ise 0 . gruba atanır. Sonrasında kestirilen değerler ile gözlemlenen gerçek değerlerin çapraz tablosu oluşturulur. Çapraz tablo yardımıyla sonucu gerçekte pozitif olanların ne kadarının pozitif (duyarlılık), negatif olanların ne kadarının negatif (seçicilik), toplamda pozitif ve negatif sonuçların ne kadarının doğru sınıflandığı hesaplanır. Modelin uyumu iyi olduğunda duyarlılık, seçicilik ve doğruluk değerlerinin yüksek olması beklenir.

Tablo 9'da 0,5 kesim noktası ve tahmin edilen olasilıklar yardımıyla her adımda sınıflandırma sonuçları verilmektedir. Tablodan genel doğru sinıflandırma oranları birinci adımda \% 69,6, ikinci adımda \% 69,6 ve 
üçüncü ve son adımda ise \% 68 olduğu görülmektedir. Ayrıca tabloda her adımda yanlış ve doğru sınıflandırılan birimlerin sayısı da verilmektedir. Sınıflandırma başarısına bakılacak olursak son adımda yüksek bir sınıflama başarısına ulaşıldığı görülmektedir. Ancak veriler üzerinde alınacak önlemler ile bu sınıflama başarısı daha iyi bir hale getirilebilinir.

Tablo 9: Sinıflama Tablosu

\begin{tabular}{|c|c|c|c|c|c|}
\hline & \multirow{3}{*}{ Gözlenen } & & \multicolumn{3}{|c|}{ Beklenen } \\
\hline & & & \multicolumn{2}{|c|}{$\begin{array}{l}\text { İnternet bankacilı̆̆ını kullanıyor } \\
\text { musunuz? }\end{array}$} & \multirow[t]{2}{*}{ Doğruluk Yüzdesi } \\
\hline & & & Hayır & Evet & \\
\hline \multirow{4}{*}{ Adım 1} & \multirow{2}{*}{$\begin{array}{l}\text { İnternet bankacilı̆̆ın kullanıyor } \\
\text { musunuz? }\end{array}$} & Hayır & 78 & 60 & 56,5 \\
\hline & & Evet & 32 & 133 & 80,6 \\
\hline & Toplam Yüzdesi & & & & 69,6 \\
\hline & İnternet bankacılığını kullanıyor & Hayır & 71 & 67 & 51,4 \\
\hline \multirow[t]{2}{*}{ Adım 2} & musunuz? & Evet & 25 & 140 & 84,8 \\
\hline & Toplam Yüzdesi & & & & 69,6 \\
\hline \multirow{3}{*}{ Adım 3} & İnternet bankacılığını kullanıyor & Hayır & 69 & 69 & 50,0 \\
\hline & musunuz? & Evet & 28 & 137 & 83,0 \\
\hline & Toplam Yüzdesi & & & & 68,0 \\
\hline
\end{tabular}

Modelin uyum iyiliğini değerlendirmek için Sınıflandırma Tablosu ve parametrelerin anlamlılığının sınanmasında kullanılan Omnibus ve Wald istatistikleri haricinde diğer yöntem ise Hosmer ve Lemeshow Testidir.. Hosmer-Lemeshow test istatistiğini hesaplamak için gereksinim duyulan gözlenen ve beklenen frekanslar Tablo $10^{\prime}$ da ve test istatistikleri Tablo $11^{\prime}$ de yer almaktadır.

Tablo 10: Hosmer-Lemeshow Test İstatistiği İçin Gözlenen ve Beklenen Frekanslar

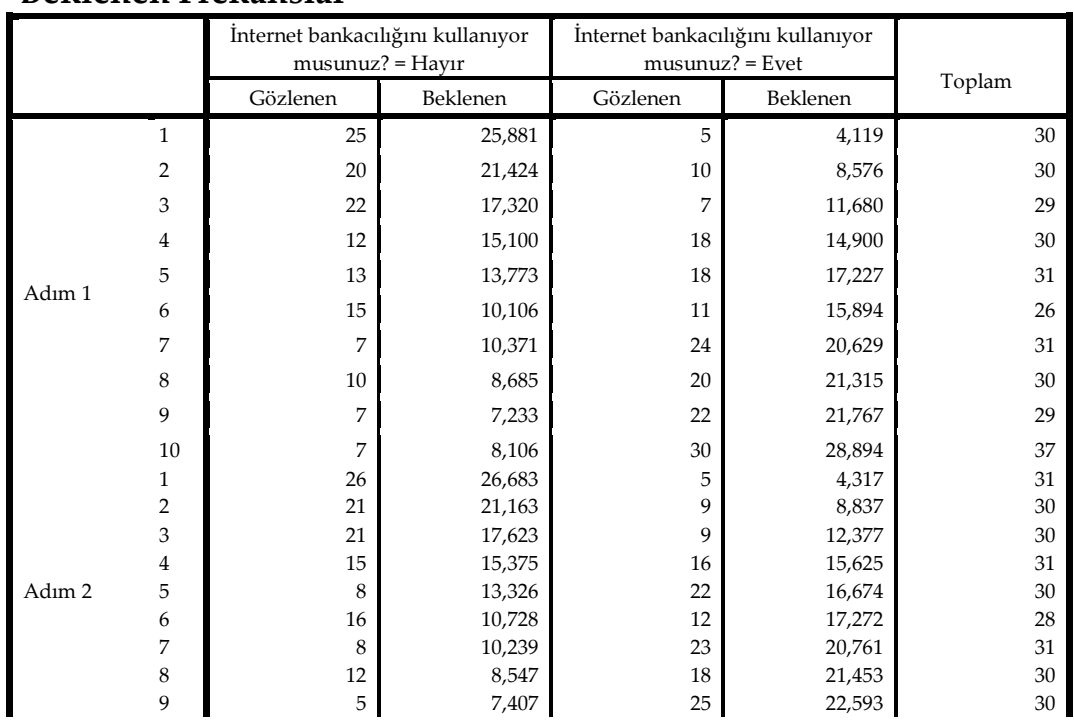




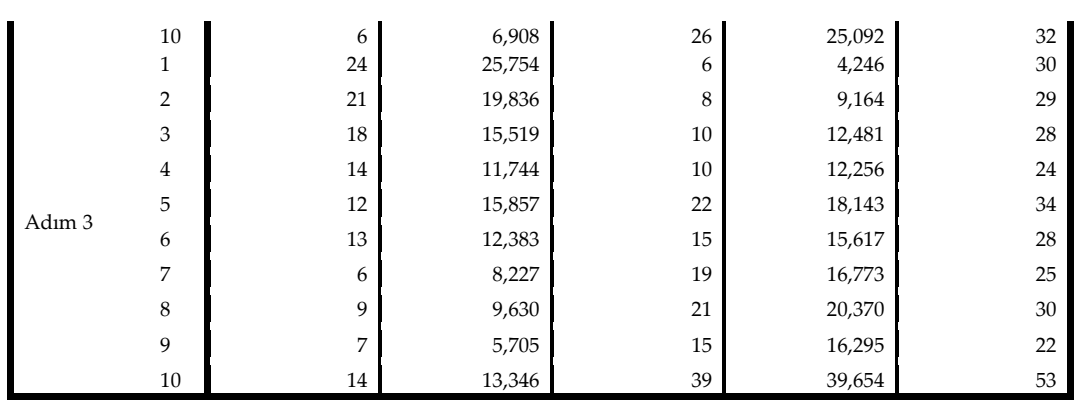

Tablo 11: Hosmer-Lemeshow Testi

\begin{tabular}{|c|c|c|c|}
\hline Adım & $\chi 2$ & df & Sig. \\
\hline 1 & 11,055 & 8 &, 199 \\
2 & 13,620 & 8 &, 092 \\
3 & 6,011 & 8 &, 646 \\
\hline
\end{tabular}

Bu istatistiğe yönelik hipotezimiz ise,

"Ho: Parametreler belirleyicilik açısından iyi bir ayrımcılığa sahiptir.

$\mathrm{H}_{1}$ : Parametreler belirleyicilik açısından iyi bir ayrımcılığa sahip değildir." şeklindedir.

Model Ki-Kare $=6,011<\chi 2(0,1 ; 8)=13,362$ olduğundan dolay1 $\mathrm{H}_{0}$ kabul edilmiş ve Lojistik Regresyon Modeli'nin internet bankacılığını kullanan ve kullanmayanları gruplara ayırmada yeterli bir model olduğu bulunmuştur. Buradan, model uyumunun oldukça iyi olduğu ve parametreler belirleyicilik açısından iyi bir ayrımcılığa sahip olduğu sonucuna varılabilir.

\section{Lojistik Regresyon Modelinin Uygunluğunun Değerlendirilmesi}

İstatistikte geliştirilen bir modelin uygunluğunun değerlendirilmesi büyük önem taşımaktadır. Bu nedenle elde edilen sonuçlar üzerinde dikkatli bir denetim yapmadan sonuç modeli kullanmamak gerekir.

$\mathrm{Bu}$ amaçla çeşitli denetim yöntemleri bulunmaktadır. Bunarın arasında açıklayıcılık katsayısının bulunması, artıkların incelenmesi (etkili, aykırı ve uzak gözlemlerin belirlenmesi), artık grafiklerin çizimi gibi yöntemler yer alır.

Doğrusal Regresyon Analizi'ndeki bağımlı değişken ile bağımsız değişkenler arasındaki ilişkiyi ölçen $\mathrm{R}^{2}$ istatistiğine benzeyen bir istatistik lojistik regresyon analizinde bulunmamaktadır. $\mathrm{Bu}$ nedenle, regresyon analizindeki $R^{2}$ değeri ile lojistik regresyon analizindeki $R^{2}$ değerini karşılaştırmak uygun değildir. Bununla birlikte literatürde lojistik regresyon analizi için birkaç $R^{2}$ istatistiğine yer verilmektedir.(Nagelkerke, 1991) 
McFaden $\mathrm{R}^{2}$, Cox-Snell ve Nagelkerke $\mathrm{R}^{2}$ istatistikleri en sık kullanılan istatistiklerdir. $\mathrm{Bu}$ istatistikler genel olarak küçük çıkma eğiliminde olduklarından farklı modellerin performansını değerlendirmek için kullanılmaları önerilmektedir. Bu nedenle bazı yazarlar sonuçlar sunulurken $R^{2}$ istatistiklerini verilmesini önermemektedir. (Alpar, 2011: 643)

Cox ve Snell $\mathrm{R}^{2}$ istatistiği olabilirlik esasına göre $\mathrm{R}^{2}$ istatistiğine benzemektedir. İstatistiğin maksimum değerinin genelde 1 'den küçük olması bu istatistiğin yorumunu güçleştirmektedir. Uygulamamızda Tablo 12 'de, Cox-Snell $\mathrm{R}^{2}$ istatistiği 3 adımda (son modelde) yaklaşık olarak \% 14,2 olarak elde edilmiştir. Bu istatistik bağımlı değişken ile bağımsız değişkenler arasında yaklaşık \% 14,2'lik bir ilişkinin olduğunu göstermektedir. (Kalaycı, 2010: 293)

Nagelkerke $R^{2}$ istatistiği ise Cox ve Snell $R^{2}$ istatistiğinin 0-1 aralığında değerler almasını sağlamak amacıyla geliştirilmiştir (Kalaycı, 2010: 293). Nagelkerke $R^{2}$ istatistiği Tablo 12 'de 3 adımda (son modelde) yaklaşık olarak \% 19 olarak elde edilmiştir. Bu istatistik bağımlı değişken ile bağımsız değişkenler arasında yaklaşık \% 19'luk bir ilişkinin olduğunu göstermektedir.

Çeşitli kaynaklarda, $\mathrm{R}^{2}$ istatistiklerinin 0,20 ile 0,40 arasında çıması yeterli olduğu açıklanmaktadır. $\mathrm{Bu}$ nedenle modelin uygunluğunun değerlendirmesinde elde edilecek olan değerin bu değerler arasında olmasını bekleriz. Sonuç olarak, elde edilen değerler bu değerler arasında olması nedeniyle kurulan modelin uygun olduğunu söyleyebiliriz. (Alpar, 2011: 666) Ayrıca -2LogL'nin her adımda model için en faydasız değişkenin çıkartılmasına karşılık artması modelin ayrı bir bakış açısından anlamlı olduğunu gösterir.

\section{Tablo 12: Modelin $R^{2}$ Tablosu}

\begin{tabular}{|c|c|c|c|}
\hline Adim & -2 Log likelihood & Cox \& Snell R & Nagelkerke R ${ }^{2}$ \\
\hline 1 & $363,575^{\circ}$ &, 163 &, 218 \\
2 & $364,077^{\circ}$ &, 162 &, 217 \\
3 & $371,260^{\circ}$ &, 142 &, 190 \\
\hline
\end{tabular}


Tablo 13: Gözlem Numarasına Göre Aykırı, Etkili ve Uzak Gözlem Grafikleri

\section{Gözlem Numarasına Göre Student Türü Artık Grafiği}

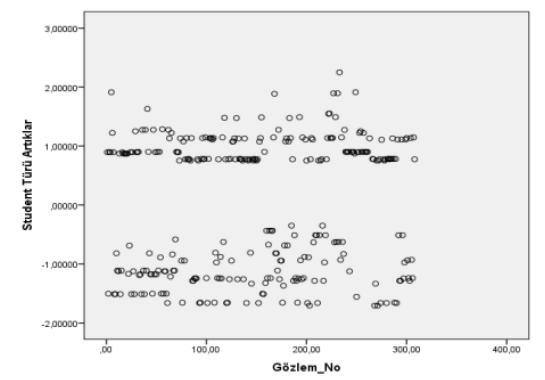

Aykırı gözlemleri incelemek için kullanılan yöntemlerden biri Student türü artıkların incelenmesidir. Student türü artıklar her bir gözlem dışarıda tutularak yapılan regresyon analizi sonuçlarına dayalı olarak hesaplanmaktadır. Student türü artıkların sıfır etrafında rasgele dağılım göstermesi ve - +2 değeri aralığında değişmesi arzu edilir. Bu sınırları aşan gözlemlerden çıkartılarak model yeniden oluşturulmalıdır. Tablo 12' de yer alan grafik incelendiğinde artık verilerin sıfır etrafında rasgele bir dağılım gösterdiği ve sadece 233. artık gözlem sınırların dışında kaldığı görülmektedir. Her ne kadar bir artık gözlemin sınırların dışında kalmasına rağmen modelin uygun ve yeterli olduğuna dair karar verebiliriz.

\section{Gözlem Numarasına Göre Cook Uzaklıkları Grafiği}

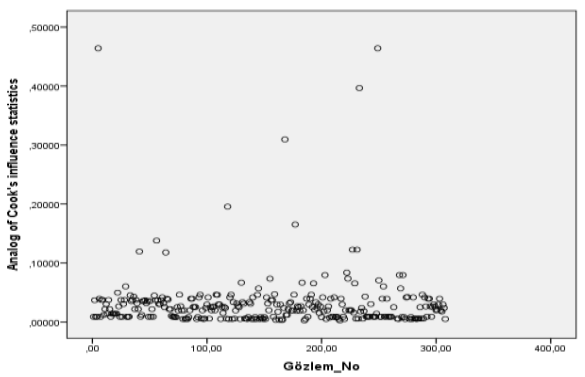

Etkili gözlemleri belirlemek için kullanılan istatistiklerden biri Cook uzaklığıdır. Cook uzaklığı değeri herhangi bir birimin model üzerindeki etkisini göstermektedir. Cook uzaklığı belirli bir birimin modelden çıkartılması durumunda lojistik regresyon katsayılarının ne kadar değişeceğini gösterir. Genellikle 1'in üzerindeki Cook değerleri etkili gözlem olarak değerlendirilir. Grafik incelendiğinde Cook uzaklığ 1 1'in üzerinde olan gözlem bulunmamaktadır. Buna karşılık 12, 269 ve 281 nolu Cook 
uzaklıkları diğer gözlemlerden farklılık göstermektedir. Ancak bu durum önemli bir durum değildir.

\section{Gözlem Numarasına Göre Leverage Uzaklıkları Grafiği}

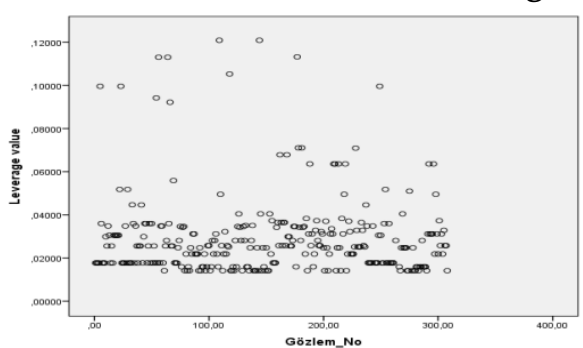

Uzak gözlemleri belirlemek için kullanılan istatistiklerden biri Leverage uzaklığıdır. Leverage değeri, $2 \mathrm{p} / \mathrm{n}$ (gözlem sayısı yeterince büyük ise)'den büyük ise gözlemler uzak gözlem olarak adlandırılır. Uzak gözlemleri incelemek için tablo 'de yer alan Gözlem No ve Leverage değerleri arasında çizilen saçılım grafiği incelendiğinde $2 * 8 / 303=0,052^{\prime}$ den büyük yaklaşık 28 gözlem yer almaktadır. Uzak gözlemler aynı zamanda etkili gözlem ise analizden çıkartılması gerekmektedir. Analizimizde böyle bir çakışma söz konusu olmadığından herhangi bir gözlemi analizden çıkartmak gereksizdir.

\section{Sonuç ve Tartışma}

$\checkmark \quad$ Kurulan modelin yapılan değerlendirmeler sonucunda uygun olduğu görülmüş ve bu konuyla ilgili Atatürk Üniversitesinde çalışan herhangi bir akademisyenin tespit edilen özellikler kullanılarak internet bankacılığı kullanıp kullanmadığı kestirilebilir. Bu kapsamda bankada çalışanlar için işlemler açısından fayda sağlayacak ve kolaylaştıracaktır.

Atatürk Üniversitesinde görev yapan akademisyenlere ilişkin Tablo 1'de yer alan;

Demografik özelliklerine ilişkin verilerin (cinsiyet, yaş, medeni durum, evli ise eşinin çalışma durumu, ev, araba ve evinde bilgisayar sahibi

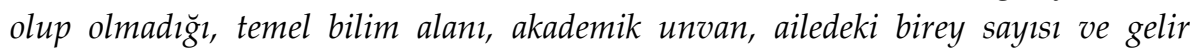
durumu) frekans dağılımı ve yüzdeleri incelediğinde, katılımclların çoğunluğunun erkeklerden, genç ve orta yaşlılardan, evli, daha çok fen ve sağlık alanında çalışan, arabası olan ve yüksek eğitimlilerden oluştuğu gözükmektedir. Gelir seviyesi de genellikle 2 bin TL'nin üstündedir.

İnternet bankacıllğının kullanılması ile ilgili bölümler incelendiğinde, banka müşterilerinin internet bankacılığını tercih etmesindeki en önemli iki faktörün "Zamandan tasarruf" ile "Bankada 
işlemler esnasında sıra beklememek" olduğu görülmektedir. Bunu sırasıyla, "rahatlığı ve çok hızlı işlem yapılabilmesi", "Kullanım kolaylığı" ve "Günün her saatinde kullanılabilmesi" izlemektedir. "İşlem maliyetinin yerinde bankacılığa oranla düşük olması" faktörü ise en son sırada yer almaktadır.

Katılımcların internet bankacılığında daha çok tercih ettikleri başlıca işlemler incelendiğinde, en fazla yapılan işlemler olarak "hesap bilgilerimi kontrol", "para transferi (havale /EFT vb.)", "kredi kartı işlemleri (hesap özeti görüntüleme, nakit avans vb.)" ve "fatura ödemeleri (elektrik, su, telefon)" işlemlerini sayabiliriz. Ayrıca, Gülmez ve Kitapçı (2006) tarafından Cumhuriyet Üniversitesi'nde yapılan çalışmada da, Cumhuriyet Üniversitesi personelinin internet bankacılığıyla yaptıkları başlıca işlemler olarak EFT işlemleri, günlük hesap hareketlerini kontrol etmek ve ödemeler belirtilmektedir. Dikkate edilecek olunursa akademik personel tarafından internet bankacılığ 1 daha çok zaman kaybettiren, rutin ve her an kontrol altında bulundurulması gereken işlemler için kullanılmaktadır. Diğer bir üniversitede bu duruma paralellik arz eden bulgulara rastlanmıştır.

İnternet bankacılığını kullanmayan katılımcıların kullanmama nedenleri incelendiğinde ise, internet bankacılığını güvensiz bulduklarından ve işlemlerin zorluğundan kullanmadıklarını belirtmişlerdir. $\mathrm{Bu}$ durum günümüzde internetin halen birçok güvenlik problemlerinin olduğunun bir göstergesi olarak değerlendirilebilinir.

Tek değişkenli lojistik regresyon analizi sonucunda ileriye dönük çoklu lojistik regresyon analizine alınan 6 değişken ile yapılan çözümleme sonuçları Tablo 7'de sunulmuştur. Çözümleme sonucunda Atatürk Üniversitesinde görev yapan akademisyenler arasında internet bankacılığı kullanmakta etkili olan yaş, araba sahipliği, temel bilim alanı ve yaş değişkenlerin önemli değişkenler olduğu tespit edilmiştir. Yapılan çözümleme sonucunda bu değişkenlere ait elde edilen odds oranlarına göre Atatürk üniversitesinde internet bankacılığını;

Cinsiyet değişkeni kapsamında; erkek akademisyenlerin bayan akademisyenlere göre 2,466 kat,

- $\quad$ Yaş değişkeni kapsamında;

* $\quad 26$ ile 35 yaş grubunda olan akademisyenlerin 25 ve daha düşük yaş grubunda olanlara göre 2,207 kat,

* 36 ile 45 yaş grubunda olan akademisyenlerin 25 ve daha düşük yaş grubunda olanlara göre 2,244 kat, 
* $\quad 46$ ile 55 yaş grubunda olan akademisyenlerin 25 ve daha düşük yaş grubunda olanlara göre 2,423 kat,

* $\quad 55$ ve daha yüksek yaş grubunda olan akademisyenlerin 25 ve daha düşük yaş grubunda olanlara göre 0,258 kat,

- $\quad$ Temel bilim alanı değişkeni kapsamında;

* $\quad$ Fen bilimleri alanında görevli akademisyenlerin sosyal bilimler alanında görevli akademisyenlere göre 2.558 kat,

* Sağlık bilimleri alanında görevli akademisyenlerin sosyal bilimler alanında görevli akademisyenlere göre 1,856 kat,

Araba sahipliği değişkeni kapsamında ise; araba sahibi olanlar olmayanlara göre ise 2,152 kat oranında kullandıkları tespit edilmiştir.

Araştırmaya göre internet bankacılığı kullanımına başlamada en önemli unsur, literatürün geneline paralel olarak "zaman” çıkmıştır. Özellikle bankaların açık olduğu saatlerin akademisyenlerin mesai saatleriyle çakışması, sıranın olması gibi nedenlerden dolayı mesai saatleri dışında gerekli olan işlemlerin yapılması için internet bankacılığı bir zorunluluk olduğu anlaşılmaktadır.

Yaş ilerledikçe internet bankacılığının kullanımı buna paralel artmaktadır. Ancak yaşın 60'ı geçtiği anda bu oran düşmektedir. Bu duruma personelin daha çok emekli olması ve işlemlerin daha çok yakınları tarafından yapıldığı düşünülmektedir.

Ayrıca dikkat çeken diğer bir konuda fen ve sağlık bilimlerinde görevli akademisyenlerin sosyal bilimlerinde görevli akademisyenlere göre internet bankacılığını daha fazla kullanması durumudur. Bu durumun gelecek çalışmalarda ayrı bir inceleme konusu olacağı değerlendirilmektedir.

\section{Kaynakça}

Akınc1, A., Aksoy, S. ve Atılgan, E. (2004). “Adoption of Internet Banking Among Sophisticated Consumer Segments in An Advanced Devaloping Country", International Journal of Bank Marketing, Vol. 22, No 3, 212-232.

Albayrak, A.S. (2006). Uygulamalı çok değişkenli İstatistik Teknikleri, 1. Baskı, Asil Yayımcılık, Ankara.

Alpar, R. (2011). Uygulamalı Çok Değişkenli İstatistiksel Yöntemler, Üçüncü Baskı, Detay Yayıncılık, Ankara.

Altan, M. ve Karasioğlu, F. (2004). Osmangazi Üniversitesi İİBF, 3. Ulusal Bilgi, Ekonomi ve Yönetim Kongresi, 25-26 Kasım 2004. 
Amin, H. (2007). "Internet Banking Adoption Among Young Intellectuals", Journal of Internet Banking and Commerce, Aralık, Vol. 12, No. 3.

Barışık, S. ve Temel, H. (2007). “ İnternet Bankacıllı̆ı̆ Kullanımında Güvenlik Unsurlarının Bilinirliğii", Kahramanoğlu Mehmetbey Üniversitesi, İïF Dergisi, Aralık, 136-160.

Berenson, M. L. ve Levine, D. M. (1996). Basic Business Statistics: Concepts and Applications, Sixth Edition, Prentice-Hall International, 837-838.

Broderick, A., J. ve Vachirapornpuk, S. (2002). “Service Quality in Internet Banking: The Importance of Custumer Role", Marketing Intelligence and Planning, Volume 20, Issue 6, 327-335, ISSN 0263-4503.

Chiemeke, S.C., Ewiekpafe, A. E., ve Chete, F. O. (2006). " The Adoption of Internet Banking in Nigeria: Empirical Investigation", Journal of Internet Banking and Commerce, Vol. 11, No. 3,

Coşkun, S., Kartal, M., Coşkun, A., ve Bircan, H. (2004). “Lojistik Regresyon Analizinin İncelenmesi ve Diş Hekimliğinde Bir Uygulaması", Cumhuriyet Üniversitesi Diş Hekimliği Fakültesi Dergisi, Cilt:7, Sayı: $1,42-50$.

Çatı, K., Öncü, M. A. ve Koçoğlu, C. M.. (2007). “Banka Müşterilerinin İnternet Bankacılığını Değerlendirmelerine Yönelik Bir Araştırma", Uluslararası 6. Bilgi, Ekonomi ve Yönetim Kongresi, 27-28-29 Aralık 2007, http://paribus.tr.googlepages.com/c_kocoglu.pdf. Erişim Tarihi: 10.06.2009.

Duruer, S., Çalışkan, A., Akbaş, H. ve Gündoğdu, C.E. (2009). “İnternet Bankacılığını Kullanma Kararını Etkileyen Faktörler: Türk Banka Müşterileri Üzerine Bir Araştırma." Marmara Üniversitesi İ.̇̇.B.F. Dergisi Cit 26 Sayı 1.

Floros, C. (2008). "Internet Banking Websites Performance in Greece", Journal of Internet Banking and Commerce, Aralık, 2008, Vol. 13, No. 3.

Gao, P. ve Owolabi, O. (2008). "Consumer Adoption of Internet Banking in Nigeria", Internatonal Journal of Electronic Finance, Vol. 2, No. 3, Ekim, 284-299.

Gülmez, M. ve Kitapçı, O. (2006). “İnternet Bankacılı̆̆ı ve Müşteri Davranışları Cumhuriyet Üniversitesi Akademik ve İdari 
Personeline Yönelik Bir Uygulama", Cumhuriyet Üniversitesi İ̈BF Dergisi, Cilt:7, Sayı:2, 83-100.

Jayawardhena, C. ve Foley, P. (2000). "Changes in the Internet banking sector- The case of internet banking in UK", Internet Research, Electronic Networking Applications and Policy, 10(1), 19-30.

IBM SPSS Regression Models 20.0.

Kalaycı, Ş. (2010). SPSS Uygulamalı Çok Değişkenli İstatistiksel Teknikleri, 5.Baskı, Asil Yayın Dağıtım, Ankara.

Kim, B.M., Widdows, R. ve Yllmazer, T. (2005). "The Determinants of Consumers' Adoption of Internet Banking", Federal Reserve Bank of Boston, Conference Series, http://www.bos.frb.org/news/conf/payments2005/yilmazer.pdf, Erişim Tarihi: 10.06.2009.

Kolodinsky, J., Hogart, J. M. ve Shue, J. F. (2000). “Bricks or Clicks? Consumer Adoption of Electronic Banking Technologies", Consumer Interest Annual, Vol. 46, 180-184.

Li, F. (2002). "Internet Banking: from new Distribution Channel to New Business Models", International Journal of Business Performance Management, Vol. 4, Issue 2-4, 136-160.

Li, S., ve Worthington, A. C. (2004). "The relationship between the adoption of Internet banking and electronic connectivity: - An International comparison." Discussion paper, School of Economics and Finance, Queensland University of Technology, Brisbane QLD, Australia.

Liao, Z. ve M. T. C. (2002). "Internet -Based E-Banking and Consumer Attitudes: An empirical Study", Information Management, 283-295.

Lichtenstein, S. ve Williamson, K. (2006). “Understanding Consumer Adoption of Internet Banking: An Interpretive Study in the Australian Banking Context", Journal of Electronic Commerce Research, Vol. 7, No. 2, 50-66.

Liu, C-C. (2008). “The relationship Between Digital Capital of Internet Banking and Business Performance", Journal of Electronic Finance, Vol. 2, No. 1, 18-30.

Matilla, M. ve Karjaluoto, H. ve Pento, T. (2003). “Internet Banking Adoption Among Mature Customer: Early Majority or Laggards?", Journal of Service Marketing, Vol. 17, No 5, 514-528. 
Migdadi, Y. K. A. (2008). “The Quality of Internet Banking Service Encounter in Jordan", Journal of Internet Banking and Commerce, Aralık, Vol. 13 , No. 3 .

Oktay, E., Kızıltan, A., Küçükali, A. ve Alkan, Ö. (2011). Kredi Kartı Sahipliğinde Etkili Olan Sosyo-ekonomik Faktörlerin Analizi: Atatürk Üniversitesi Öğrencileri Üzerine Bir Uygulama. Eser Ofset Matbaacılık, Erzurum.

Özdamar, K., Paket Programlar ile İstatistiksel Veri Analizi, Cilt 1, Kaan Kitabevi, 2. Baskı, 1999, Eskişehir.

Padachi, K., Rojid, S. ve Seetanah, B., (2007), "Analyzing the Factor That Influence the Adoption of Internte Banking in Mauritius", Proceeding of 2007 Computer Science an IT Education Conference.

Pala, E.ve Kartal, B.(2010), Banka Müşterilerinin İnternet Bankacılığı ile İlgili Tutumlarına Yönelik Bir Pilot Araştırma, Yönetim ve Ekonomi Dergisi, Cilt:17 Sayı:2

Pew, (2003). "Convenience is King", Pew Internet and American Life Project, Retrieved from World Wide Web on 15 February 2006, www.pewInternet.org/reports.asp?

Report=77\&Section=ReportLevel1\&Field=Level1ID\&ID=342, Erişim Tarihi: 21.12.2012.

Polatoğlu, V. N. ve Ekin, S. (2001). "An Empirical Investigationof the Turkish Consumers' Acceptanceof Internet Banking Services", International Journal of Bank Marketing, 19 (4), pp. 156-165.

Rochanakitumnual, S. ve Speece, M. (2003). "Barriers to Internet Banking Adoption: Aqualitative Study Among Corporate Customers in Thailand", International Journal of Bank Marketing, 21 6/7, 312-323.

Sathye, M. (1999). “Adoption of Internet Banking by Australian Consumers: An Emprical Investigation, International Journal of Bank Marketing, 17 (7), 324-334.

Shergill, G. S. ve Li, B. (2005). "Internet Banking- An Empirical Investigation of Customers' Behaviour for Online Banking in Nez Zealand", Journal of E-Business, Vol. 5, No. 1, 1-16. 
Sohail, M.S. ve Shanmugham, B. (2000). "E-banking and Customer Preferences in Malaysia: An Empirical Investigation", Information Science, 150, 207-217.

Sun, B. ve Han, I. (2002). "Effect of Trust on Customer Acceptance of Internet Banking", Electronic Commerce Research and Applications, 1, 247263.

Ulupınar, S. D. (2007). 2001 Kriz Dönemi, Öncesi ve Sonrasında Türk Ticari Bankalarının Karlılıklarının Lojistik Regresyon Analizi ile İncelenmesi, İstatistik Bilim Dalı Yüksek Lisans Tezi, Marmara Üniversitesi, İstanbul.

Usta, R. (2005). “Tüketicilerin İnternet Bankacılığını Kullanmama Nedenleri Üzerine Bir Araştırma", Doğuş Üniversitesi Dergisi, 6(2), 279-290.

Ustasüleyman, T. ve Eyüboğlu, K.(2010) Bireylerin İnternet Bankacılığını Benimsemesini Etkileyen Faktörlerin Yapısal Eşitlik Modeli ile Belirlenmesi. BDDK Bankacilık ve Finansal Piyasalar Dergisi, Cilt:4, Sayi:2.

Yılmaz, H. (2006). "Bilgi ve İletişim Teknolojilerindeki Gelişmelerin Bankacılık İşlemleri Üzerine Etkileri", Paradoks, Ekonomi, Sosyoloji ve Politika Dergisi, (e-dergi), Y11:2, Say1:2, ISSN 1305-7979.

http://www.webrazzi.com/2011/10/18/comscore-avrupa-en-aktif-internetkullanicilari-turkiye/ Erişim Tarihi 03.01.2013 